MATHEUS CARNEIRO ASSUNÇÃO

\title{
O PRINCÍPIO DA TRANSPARÊNCIA NO DIREITO FINANCEIRO BRASILEIRO
}

\author{
Tese de Doutorado \\ Orientador: Professor Associado Dr. Fernando Facury Scaff
}

UNIVERSIDADE DE SÃO PAULO

FACULDADE DE DIREITO

SÃO PAULO-SP 


\section{O PRINCÍPIO DA TRANSPARÊNCIA NO DIREITO FINANCEIRO BRASILEIRO}

Tese de Doutorado, apresentada à Banca Examinadora do Programa de Pós-graduação em Direito da Faculdade de Direito da Universidade de São Paulo, na área de concentração de Direito Econômico e Financeiro, sob a orientação do Professor Associado Doutor Fernando Facury Scaff.

UNIVERSIDADE DE SÃO PAULO

FACULDADE DE DIREITO

SÃO PAULO-SP 


\section{Catalogação da publicação}

Serviço de Biblioteca e Documentação

Faculdade de Direito da Universidade de São Paulo

\section{Assunção, Matheus Carneiro}

O Princípio da transparência no direito financeiro brasileiro / Matheus Carneiro Assunção ; orientador Fernando Facury Scaff - São Paulo, 2017

$370 \mathrm{p}$.

Tese (Doutorado - Programa de Pós-graduação em Direito Econômico, Financeiro e Tributário) - Faculdade de Direito Universidade de São Paulo, 2017.

1. Direito financeiro. 2. Princípio constitucional. 3. Transparência. 4. Democracia. 5. Controle. I. Scaff, Fernando Facury, orient. II. Título. 


\section{O PRINCÍPIO DA TRANSPARÊNCIA NO DIREITO FINANCEIRO BRASILEIRO}

Tese de Doutorado, apresentada à Banca Examinadora do Programa de Pós-graduação em Direito da Faculdade de Direito da Universidade de São Paulo, na área de concentração de Direito Econômico e Financeiro, sob a orientação do Professor Associado Doutor Fernando Facury Scaff.

\section{JULGAMENTO:}

\section{BANCA EXAMINADORA:}

Presidente: Professor Associado Fernando Facury Scaff

Instituição: Faculdade de Direito - USP

Assinatura:

Professor:

Instituição: Assinatura:

Professor:

Instituição: Assinatura:

Professor:

Instituição:

Assinatura:

Professor:

Instituição:

Assinatura:

Professor:

Instituição:

Assinatura: 
Aos meus pais, na transparência dos sentimentos mais essenciais da vida, invisiveis aos olhos. 


\section{AGRADECIMENTOS}

Este trabalho marca a conclusão de uma longa jornada acadêmica percorrida na Faculdade de Direito da Universidade de São Paulo, com a qual sonhava desde os tempos da minha graduação, na Faculdade de Direito do Recife. Era um sonho distante, mas acabou virando realidade.

Algumas pessoas tiveram papel essencial na realização deste sonho, e perante elas mantenho dívidas de gratidão impagáveis. O débito mais antigo e de valor inestimável acumulei com o Professor FERNANDO FAcURY ScAFF. Não apenas por confiar nos meus projetos, mas sobretudo por guiar-me na travessia do imaginado ao concretizado, do invisível ao tangível, dando-me liberdade para traçar a rota.

Como diz o Professor José Souto MAIOR BORGES, "num horizonte infinito de possibilidades abertas ao pensamento, cada um deve escolher o seu próprio itinerário" ${ }^{1}$. O percurso, porém, tende a ser mais seguro quando orientado por viajantes experientes. Do Professor SCAFF, experiente navegador nas caudalosas águas do direito financeiro brasileiro, tive o privilégio de receber preciosas dicas de itinerário durante os últimos anos. Sem ele, eu não teria chegado até aqui.

$\mathrm{Na}$ vida, o tempo sempre é insuficiente para tudo aquilo que imaginamos fazer. Ele corre a passos largos e, por vezes, na fuga dos dias, não conseguimos colocar em prática objetivos inicialmente planejados, que acabam ficando para trás. Mas "cada coisa a seu tempo tem seu tempo" - lembra-nos outro Fernando (o Pessoa) -, e o término deste trabalho acabou sendo imposto pelo seu tempo, limitado pela data final de depósito. Produto de reflexões e inquietações ainda vicejantes, certamente merecerá reformulações, após as considerações críticas dos membros da banca examinadora, a quem antecipadamente consigno meus sinceros agradecimentos.

As críticas que já recebi por ocasião da qualificação foram essenciais à melhoria do projeto. Neste ponto, registro reconhecimento especial aos Professores que dela participaram. Ao Professor José LeVI MELLo do AmARAL

\footnotetext{
${ }^{1}$ BORGES, José Souto Maior. Ciência feliz. 3. ed. São Paulo: Quartier Latin, 2007, p. 29.
} 
JúNIOR, por quem nutro profunda admiração, não apenas no âmbito acadêmico, mas também no campo da advocacia pública federal, serei sempre grato pelas sugestões de melhoramentos de tópicos e abordagem de assuntos não pensados inicialmente, com a sua típica humildade, atenção e disposição em ajudar. Agradeço igualmente ao Professor HeLENO TAVEIRA TORRES - cujas obras foram esseciais à confecção da tese - pelos comentários formulados naquela oportunidade.

Não poderia deixar de fazer gratulações a três outros professores com quem tive o prazer de estudar: ao Professor REgIS FERNANDES DE OLIVEIRA, pela visão peculiar do direito financeiro, compartilhada com seus alunos; e aos Professores EsteVÃo HoRVATH e José MAURícIo CONTI, pelas lições das aulas de pós-graduação e das monitorias nas disciplinas da graduação.

Agradeço também ao meu amigo SÉRgIO VASCONCELOS, pelas proveitosas sugestões e pelas conversas sempre enriquecedoras.

Sou grato, enfim, a todos que de alguma forma me auxiliaram a conceber este trabalho, seja pelas informações hauridas das referências bibliográficas, seja pelo agradável e profícuo convívio acadêmico.

Muito aprendi, e certamente continuarei a aprender, mesmo após deixar de ser aluno da "velha e sempre nova" Academia de Direito do Largo São Francisco. Levo uma parte dela em mim. 
"Nem tudo é claro na vida ou nos livros"

(Machado de Assis)

"Tudo vem dos sonhos. Primeiro sonhamos, depois fazemos".

(Monteiro Lobato) 


\section{RESUMO}

ASSUNÇÃO, M. C. O princípio da transparência no direito financeiro brasileiro. 2017. 370 p. Tese (Doutorado em Direito) - Faculdade de Direito, Universidade de São Paulo, 2017.

A tese sustenta que o princípio da transparência, no direito financeiro brasileiro, busca promover a acessibilidade, a inteligibilidade e a confiabilidade das informações sobre a atividade financeira do Estado Democrático de Direito, em todos os níveis de governo, de maneira a assegurar a controlabilidade do exercício do poder político-financeiro. Partindo da gênese e significação do conceito de transparência, o estudo pretende delimitar os fundamentos e a estrutura normativa desse princípio jurídico, fornecendo elementos para a análise da sua efetividade na dinâmica da atividade financeira do Estado. Nessa linha, o trabalho divide-se em três partes inter-relacionadas. Na primeira parte, é feita uma retrospectiva histórica das origens da ideia de transparência e das suas percepções e assimilações no campo das finanças públicas, seguida da exposição de uma perspectiva semântica tridimensional (fática, axiológica e normativa), balizadora da definição do conceito de transparência. Na segunda parte, são investigados os fundamentos constitucionais e infraconstitucionais do princípio, e relacionados os seus aspectos normativos estruturais. Na terceira parte, são analisados problemas relativos à aplicação do princípio, envolvendo a dinâmica do planejamento e da execução do orçamento, da arrecadação de receitas públicas, da realização de despesas e do endividamento público. Por derradeiro, apresentam-se conclusões no sentido de que existem zonas de opacidade a serem enfrentadas na trilha de realização do princípio da transparência, a fim de melhorar a visibilidade das finanças públicas e seu controle democrático no Brasil.

Palavras-chave: direito financeiro; princípio constitucional; transparência; democracia; controle. 


\begin{abstract}
ASSUNÇÃO, M. C. The principle of transparency in Brazilian public finance law. 2017. 370 p. Thesis (Ph.D) - Faculty of Law, University of São Paulo, 2017.

This thesis argues that the principle of transparency, in Brazilian public finance law, intends to promote accessibility, intelligibility and confiabillity of information regarding the financial activity of the Democratic State of Law, in all levels of government, in a way to assure the controllability of political and financial power. Exposing the origins and the meanings of transparency, the study seeks to delimit the normative basis and structure of this legal principle, providing elements to analyze its effectiveness in the dynamics of public finance. Therefore, this thesis is divided in three parts interrelated. In the first part, it is shown a historical retrospective of the idea of transparency and its assimilations in public finance, considering three semantical dimensions (factual, axiological and normative). In the second part, it is examined the constitutional and legal foundations of the principle, as well as its normative structure. In the third part, practical aspects related to the use of the principle are investigated, in the dynamics of budget planning and execution, revenue collection, public expenditure and public indebtedness. Finally, the thesis concludes that there are opaque zones to be faced on the path to enforce the principle of transparency, in order to improve the visibility of public finance and its democratic control in Brazil.
\end{abstract}

Keywords: public finance law; constitutional principle; transparency; democracy; control. 


\section{RIASSUNTO}

ASSUNÇÃO, M. C. Il principio della trasparenza nel diritto finanziario brasiliano. 2017. Tesi (Dottorato in Diritto) - Facoltà di Diritto, Università di São Paulo.

La tesi sostiene che il principio della trasparenza, nel diritto finanziario brasiliano, vuole promuovere l'accessibilità, l'intelligibilità e l'affidabilità delle informazioni sull'attività finanziaria dello Stato Democratico di Diritto, in tutti i livelli di governo, in modo di assicurare il controllo del potere politico-finanziario. Partendo dalla genesi e dal significato del concetto di trasparenza, lo studio pretende delimitare le basi e la struttura normativa di questo principio giuridico, fornendo elementi per l'analisi della sua effettività nella dinamica dell'attività finanziaria dello Stato. Su questa linea, il lavoro si divide in tre parti interconnesse. Nella prima parte è eseguita una retrospettiva storica delle origini dell'idea di trasparenza e delle sue percezioni e assimilazioni nel campo delle finanze pubbliche, seguita dall'esposizione di una prospettiva semantica tridimensionale (fàtica, assiologica e normativa), manovrante della definizione del concetto di trasparenza. Nella seconda parte, sono investigate le basi costituzionali e sottocostituzionali del principio e in relazione con i suoi aspetti normativi strutturali. Nella terza parte, sono analizzati problemi relativi all'applicazione del principio, coinvolgendo la dinamica della pianificazione e dell'esecuzione del bilancio, dell'incasso delle entrate pubbliche, della realizzazione di spese e del debito pubblico. Infine, si presentano le conclusioni analizzando il significato in cui esistono zone di opacità che devono essere affrontate sul cammino della realizzazione del principio della trasparenza, con l'obbiettivo di migliorare la visibilità delle finanze pubbliche e il suo controllo democratico in Brasile.

Parole chiave: diritto finanziario; principio costituzionale; trasparenza; democrazia; controllo. 


\section{LISTA DE ABREVIATURAS E SIGLAS}

$\begin{array}{ll}\text { ACP } & \text { Ação Civil Pública } \\ \text { ADI } & \text { Ação Direta de Inconstitucionalidade } \\ \text { ADPF } & \text { Arguição de Descumprimento de Preceito Fundamental } \\ \text { AGU } & \text { Advocacia-Geral da União } \\ \text { AgR } & \text { Agravo Regimental } \\ \text { BC } & \text { Banco Central do Brasil } \\ \text { BNDES } & \text { Banco Nacional de Desenvolvimento Econômico e Social } \\ \text { CF/88 } & \text { Constituição da República Federativa do Brasil de 1988 } \\ \text { CMN } & \text { Conselho Monetário Nacional } \\ \text { CNJ } & \text { Conselho Nacional de Justiça } \\ \text { CPI } & \text { Comissão Parlamentar de Inquérito } \\ \text { CTN } & \text { Código Tributário Nacional } \\ \text { DJ } & \text { Diário da Justiça } \\ \text { DJe } & \text { Diário da Justiça Eletrônico } \\ \text { EUA } & \text { Estados Unidos da Améria } \\ \text { FMI } & \text { Fundo Monetário Internacional } \\ \text { FOIA } & \text { Freedom of Information Act } \\ \text { LAI } & \text { Lei de Acesso à Informação } \\ \text { LC } & \text { Lei Complementar } \\ \text { LDO } & \text { Lei de Diretrizes Orçamentárias } \\ \text { LOA } & \text { Lei Orçamentária Anual } \\ \text { LRF } & \text { Lei de Responsabilidade Fiscal } \\ \text { MC } & \text { Medida Cautelar } \\ \text { Min. } & \text { Ministro(a) } \\ \text { MPF } & \text { Ministério Público Federal } \\ \text { MS } & \text { Mandado de Segurança } \\ \text { RMS } & \text { Recurso Ordinário em Mandado de Segurança } \\ \text { ONG } & \text { Organização não governamental } \\ \text { OS } & \text { Organização Social } \\ \text { OSCIP } & \text { Organização da Sociedade Civil de Interesse Público } \\ \text { RE } & \text { Recurso Extraordinário } \\ \text { REsp } & \text { Recurso Especial } \\ \text { RMS } & \text { Recurso em Mandado de Segurança } \\ \text { PGFN } & \text { Procuradoria-Geral da Fazenda Nacional } \\ \text { PPA } & \text { Plano Plurianual } \\ \text { Rcl } & \text { Reclamação } \\ \text { Rel. } & \text { Relator(a) } \\ \text { SPE } & \text { Sociedade de Propósito Específico } \\ \text { STJ } & \text { Superior Tribunal de Justiça } \\ \text { STN } & \text { Secretaria do Tesouro Nacional } \\ \text { STF } & \text { Supremo Tribunal Federal } \\ \text { TCU } & \text { Tribunal de Contas da União } \\ & \end{array}$




\section{SUMÁRIO}

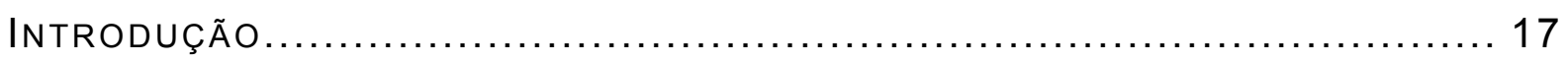

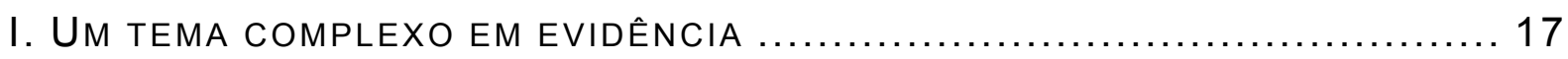

II. MotIVOS CONDUTORES ................................................ 22

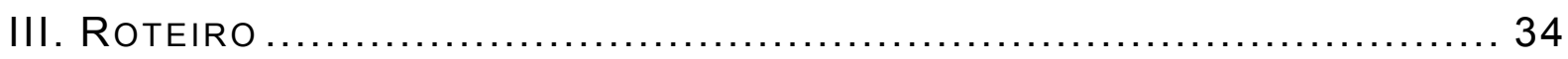

Primeira Parte - Gênese E significaÇão da transparênCIA ............. 37

CAPÍTULO 1 - ORIGEM E EVOLUÇÃO DA TRANSPARÊNCIA NAS FINANÇAS

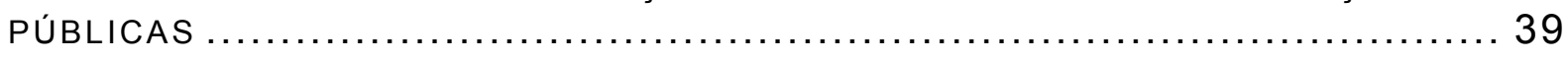

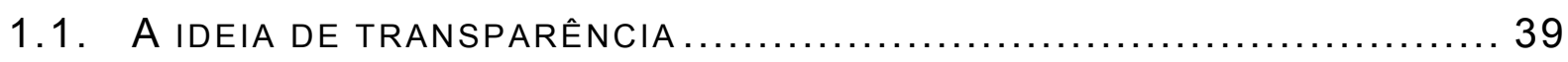

1.2. Genealogia da transparência nas finanças PÚblicas $\ldots \ldots \ldots \ldots 43$

1.3. EVOLUÇÃO HISTÓRICA DA TRANSPARÊNCIA NO BRASIL ................58

1.4. A transparência no atual Estado Democrático de Direito .....64

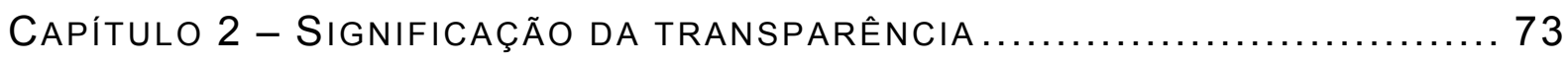

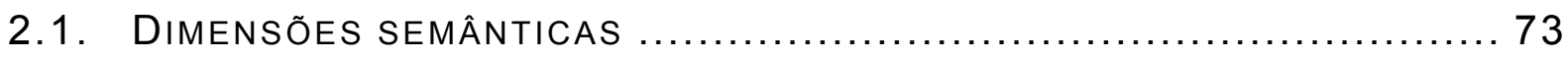

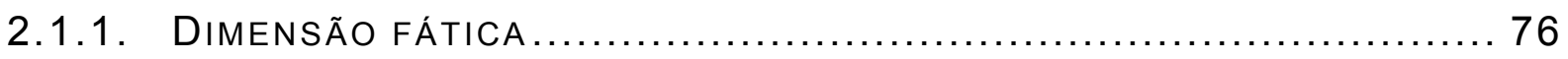

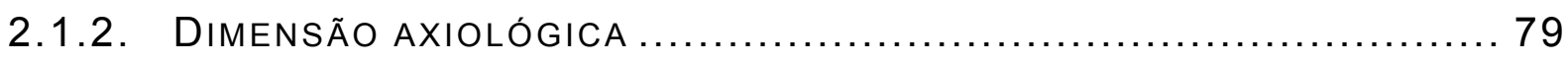

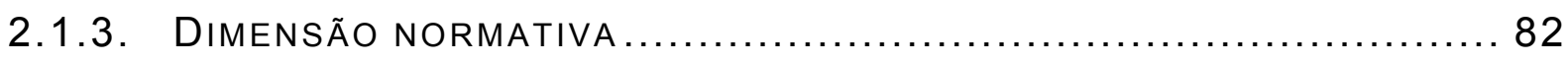

2.1.3.1. SEPARAÇÕES E RELACIONAMENTOS ENTRE REGRAS E PRINCíPIOS 83

2.1.3.2. CRITÉRIOS PARA A APLICAÇÃO DE PRINCÍPIOS ..................... 88

2.1.3.3. A TRANSPARÊNCIA COMO PRINCÍPIO DO DIREITO FINANCEIRO ..... 90 SEgUNDA PARTE - FUNDAMENTAÇÃO E ESTRUTURAÇÃO NORMATIVA DA

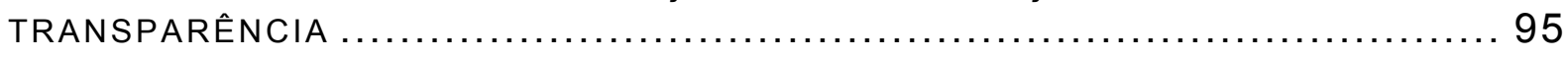

CAPÍTULO 3 - FUNDAMENTOS DO PRINCÍPIO DA TRANSPARÊNCIA ............. 98

3.1. FUNDAMENTOS CONSTITUCIONAIS ................................... 99

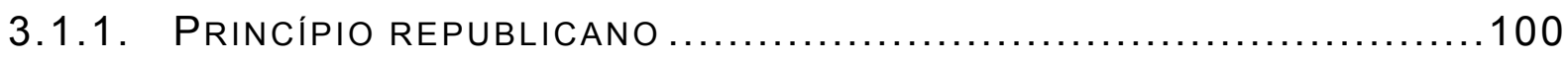

3.1.2. PRINCÍPIO DEMOCRÁTICO ....................................... 102

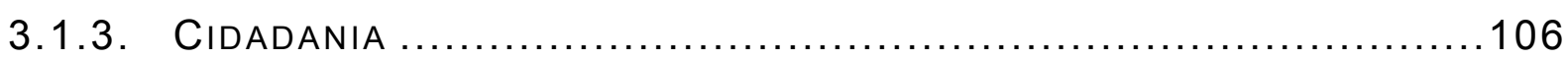

3.1.4. DiREITO FUndamEnTAL DE ACESSO À INFORMAÇÃO ..................107

3.1.5. PRINCÍPIO DA SEGURANÇA JURÍDICA .............................111

3.1.6. DEVER DE PRESTAÇÃO DE CONTAS ................................112

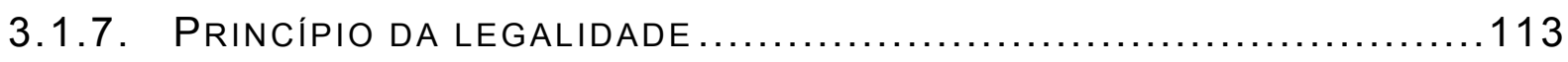

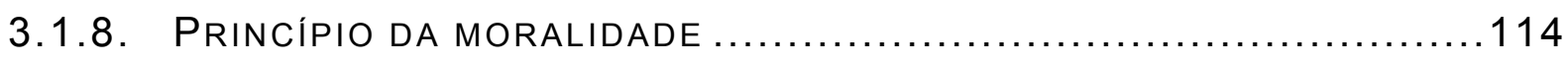

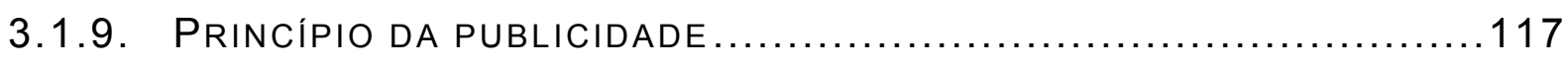


3.1.10. PRINCÍPIO DA PARTICIPAÇÃO SOCIAL NA ADMINISTRAÇÃO ..........120

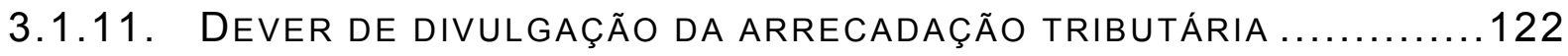

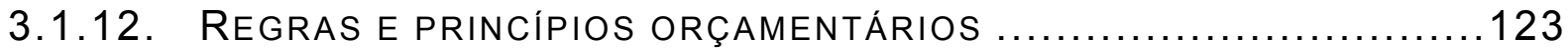

3.2. Fundamentos INFRACONSTITUCIONAIS ............................ 126

3.2.1. CONTROLE CONTÁBIL, FINANCEIRO E ORÇAMENTÁRIO $\ldots \ldots \ldots \ldots \ldots . . . . .127$

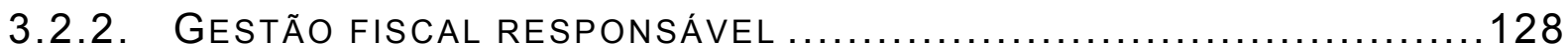

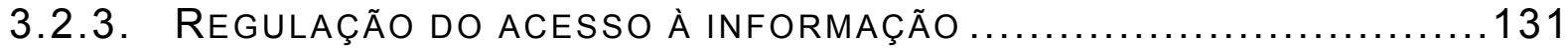

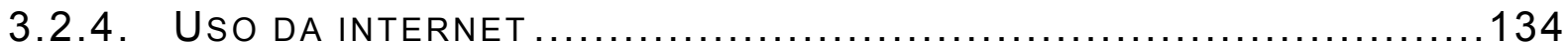

CAPÍTULO 4 - ESTRUTURA do PRINCÍPIO DA TRANSPARÊNCIA ...............136

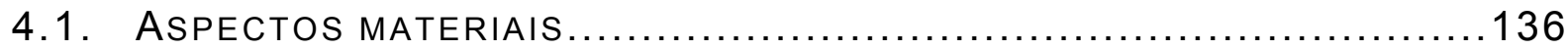

4.1.1. ACESSIBILIDAdE ............................................... 139

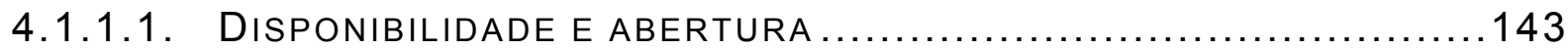

4.1.1.2. RESTRIÇÕES ................................................... 149

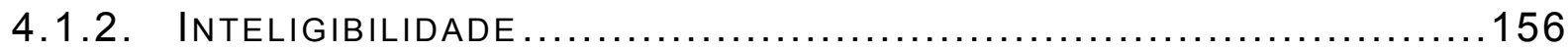

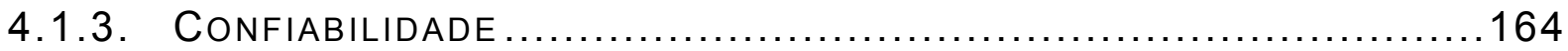

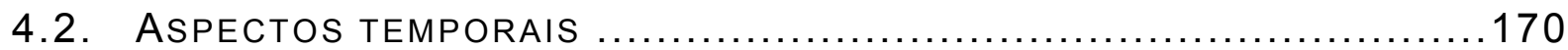

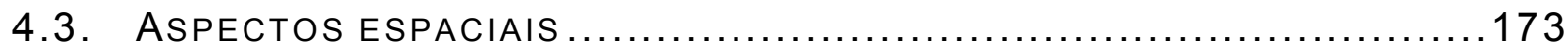

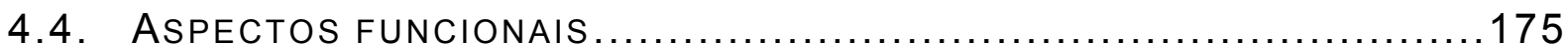

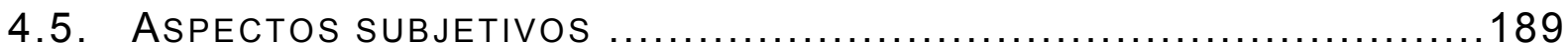

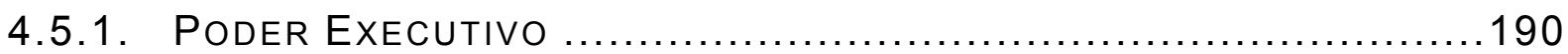

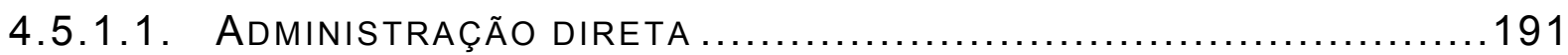

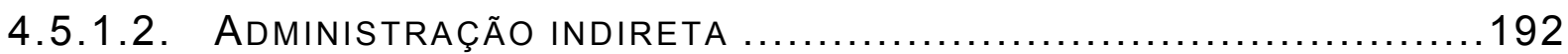

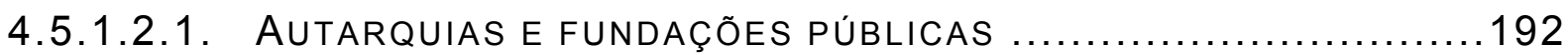

4.5.1.2.2. EMPRESAS PÚBLICAS E SOCIEDADES DE ECONOMIA MISTA ......195

4.5.2. POdER Legislativo ............................................. 199

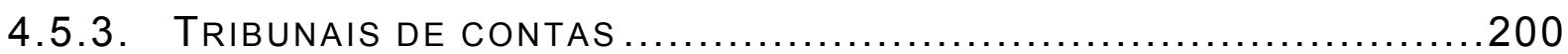

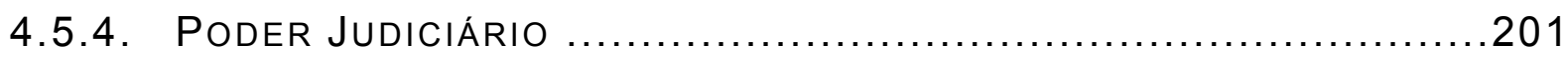

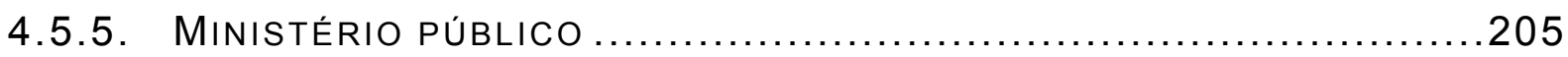

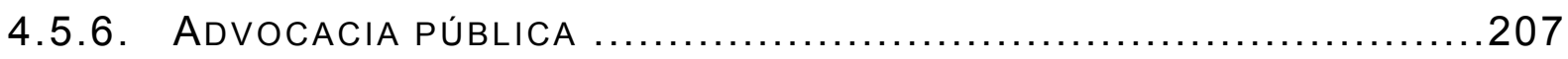

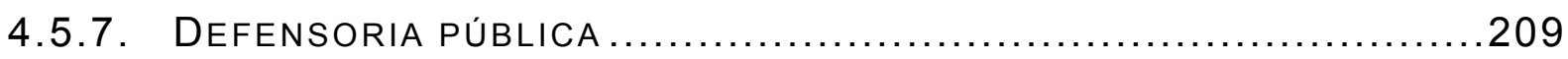

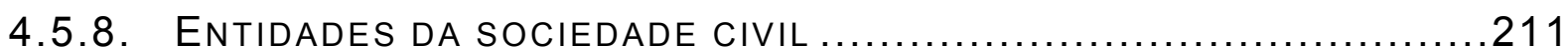

4.5.9. Titulares de direitos Subjetivos a INFORMAÇões PúblicAS ...214

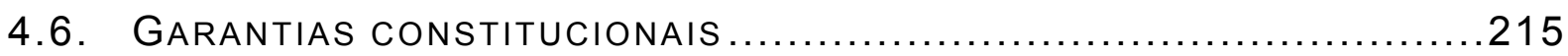

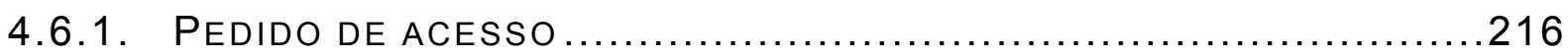

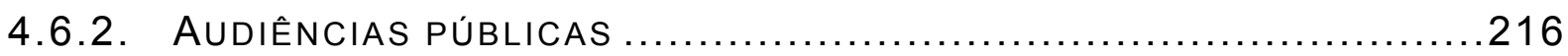




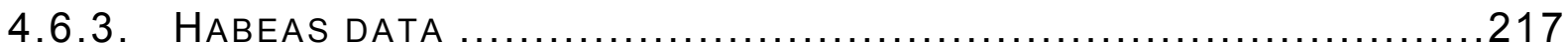

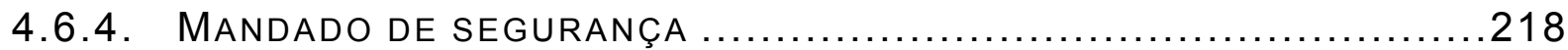

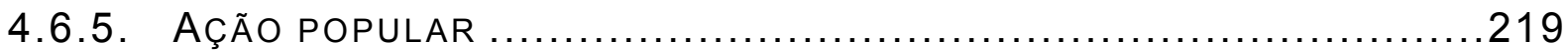

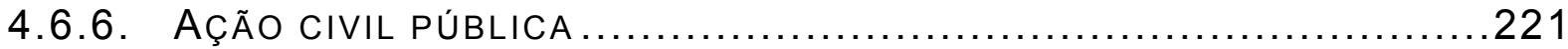

TERCEIRA PARTE - EFICÁCIA DO PRINCÍPIO DA TRANSPARÊNCIA NA ATIVIDADE FINANCEIRA DO ESTADO DEMOCRÁTICO DE DIREITO ...............223

CAPÍTULO 5 - TRANSPARÊNCIA NO PLANEJAMENTO, NA EXECUÇÃO

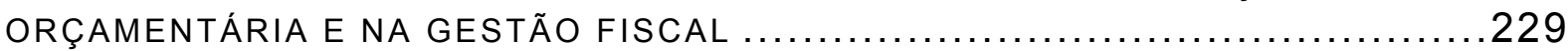

5.1. TRANSPARÊNCIA No PLANEJAMENTO DA AÇÃo goVERNAMENTAL ......230

5.2. TRANSPARÊNCIA NA tRÍAdE ORÇAMENTÁRIA: PPA, LDO E LOA ......233

5.3. TRANSPARÊNCIA NA POLÍTICA FISCAL ...............................246

5.4. TRANSPARÊNCIA NaS POLÍticas MONETÁRIA, CREDITÍCIA E CAMBIAL .250

5.5. TRANSPARÊNCIA NA ESTIMATIVA dA ARRECADAÇÃO $\ldots \ldots \ldots \ldots \ldots \ldots . \ldots . \ldots . \ldots . \ldots 256$

5.6. EXPECTATIVAS ORÇAMENTÁRIAS LEgÍTIMAS ..........................258

5.7. TRANSPARÊNCIA NA EXECUÇÃo ORÇAMENTÁRIA E NA GESTÃo FISCAL 260

5.8. TRANSPARÊNCIA NA PRESTAÇÃO DE CONTAS ...........................264

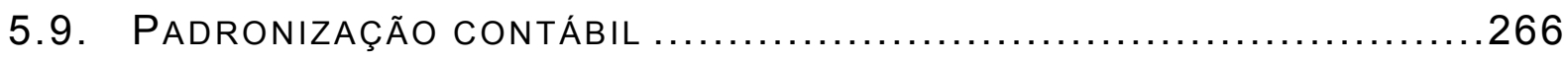

5.10. ContabILIDAdE CRIATIVA E ILUSÕES fISCAIS .......................269

CAPÍtulo 6 - TRANSPARÊNCIA NA ARRECAdAÇÃo de RECEITAS PÚblicas .276

6.1. TRANSPARÊNCIA NAS RECEITAS TRIBUTÁRIAS .......................277

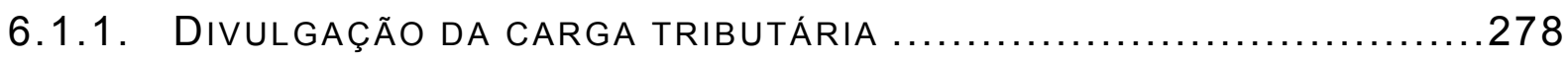

6.1.2. ACESSO A INFORMAÇÕES DE INTERESSE DO CONTRIBUINTE .........281

6.1.3. INFORMAÇÕES DA DíVIDA ATIVA E LISTAS DE DEVEDORES ............283

6.2. TRANSPARÊNCIA DAS RECEITAS NÃO TRIBUTÁRIAS ....................286

6.3. TRANSPARÊNCIA NA REPARTIÇÃo dE RECEITAS PÚBlICAS .............290

CAPÍTULO 7 - TRANSPARÊNCIA NAS DESPESAS PÚBlICAS ...................293

7.1. DESPESAS SIGILOSAS ............................................. 298

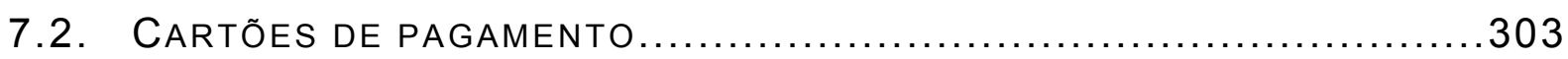

7.3. TRANSPARÊNCIA NAS DESPESAS COM PESSOAL.......................306

7.3.1. DIVULGaÇÃO DE REMUNERAÇÕES E PROTEÇÃO DA INTIMIDADE ......307

7.3.2. FALTA DE UNIFORMIDADE DOS CRITÉRIOS DE APURAÇÃO .............314

7.4. TRANSPARÊNCIA NOS GASTOS TRIBUTÁRIOS ...........................316

7.5. TRANSPARÉNCIA NOS SUBSÍdIOS CREDITÍCIOS E FINANCEIROS ..........320

CAPÍTULO 8 - TRANSPARÊNCIA NO CRÉdITO PÚBLICO ........................322

8.1. CRÉdITO PÚBLICO: A CONFIANÇA POR MEIO DA TRANSPARÊNCIA.......323

8.2. TRANSPARÊNCIA NA DÍVIDA PÚBLICA ...............................327 
8.3. EMPRÉSTIMOS SUBSIDIADOS COM RECURSOS PÚBLICOS 332

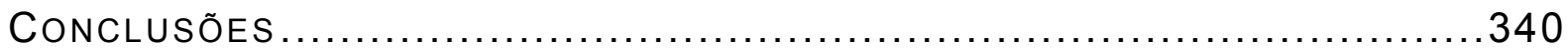
REFERÊNCIAS BIBLIOGRÁFICAS ........................................... 343 


\title{
INTRODUÇÃO
}

"Do que digo, descubro, deduzo. Será, se? Apalpo o evidente? Tresbusco."

(João Guimarães Rosa)

"Tu vens, tu vens,

Eu já escuto os teus sinais"

(Alceu Valença)

\section{UM TEMA COMPLEXO EM EVIDÊNCIA}

\begin{abstract}
A transparência é um tema em grande evidência no cenário democrático contemporâneo. É também um tema sobremodo complexo, que transpassa diferentes campos do conhecimento.
\end{abstract} No âmbito jurídico, debates sobre transparência vêm ganhando
projeção exponencial internacionalmente ${ }^{2}$, sobretudo com os vertiginosos

\footnotetext{
${ }^{2}$ As legislações de diversos países têm sido modificadas para assegurar a transparência pública, como demonstram o Freedom of Information Act, de 2000, na Inglaterra; a Ley Federal de Transparencia y Acceso a la Información Pública Gubernamental, de 2002, no México; a Informationsfreiheitsgesetz (Gesetz vom 05.09.2005), na Alemanha; a Ley 19/2013 na Espanha; o Decreto Legislativo n. 33/2013, na Itália, dentre outros diplomas normativos. No campo doutrinário, sob o ângulo jurídico, vários estudos sobre transparência foram publicados no último decênio: COTINO HUESO, Lorenzo. Transparencia y derecho de acceso a los documentos en la Constitución Europea y en la realidad de su ejercicio. Valencia: Tirant lo Blanch, 2006; MERLONI, Francesco (Org.). La trasparenza amministrativa. Milano: Giuffré, 2008; ACKERMAN, John M. (Coord.). Más allá del acceso a la información: transparencia, rendición de cuentas y Estado de derecho. México: Siglo XXI, 2008; DRIESSEN, Bart. Transparency in EU institutional law: a practitioner's handbook. London: Cameron May, 2008. ASSONI FILHO, Sérgio. Transparência fiscal e democracia. Porto Alegre: Núria Fabris, 2009; MARTINS JÚNIOR, Wallace Paiva. Transparência administrativa: publicidade, motivação e participação popular. 2 ed. São Paulo: Saraiva, 2010; BIANCHI, Andrea; PETERS, Anne (Ed.). Transparency in international law. New York: Cambridge University Press, 2013; WENCES, Isabel; KÖLLING, Mario; RAGONE, Sabrina (Coord.). La ley de transparencia, acceso a la información pública y buen gobierno: una perspectiva académica. Madrid: CEPC, 2014; GUICHOT, Emilio (Coord.). Transparencia, acceso a la información pública y buen gobierno: estudio de la ley 19/2013, de 9 de diciembre. Madrid: Tecnos, 2014; dentre outros, referenciados ao final deste trabalho.
} 
avanços das novas tecnologias. Em uma sociedade cada vez mais interconectada e baseada em fluxos contínuos de informações, a transparência assume importância ímpar na regulação das relações intersubjetivas, especialmente no que tange à atuação do Estado.

No Brasil, inovações legislativas foram introduzidas ao longo dos últimos anos fortalecendo a transparência no Estado Democrático de Direito contemporâneo: a Lei Complementar n. 131/2009, modificativa da Lei de Responsabilidade Fiscal (Lei Complementar n. 101/2000), a Lei de Acesso à Informação (Lei n. 12.527/2011), e o Marco Civil da Internet (Lei n. 12.965/2014).

Abriram-se amplas janelas normativas para possibilitar maior visibilidade da esfera pública. Visibilidade, aliás, já prevista na Constituição de 1988, que elencou o acesso à informação como direito fundamental (art. $5^{\circ}, \mathrm{XIV}$ e XXXIII), a publicidade como princípio da Administração Pública (art. 37, caput), a garantia de acesso dos usuários a registros administrativos e a informações sobre atos de governo (art. 37, $\S 3^{\circ}$, II), o dever de disponibilização de contas públicas

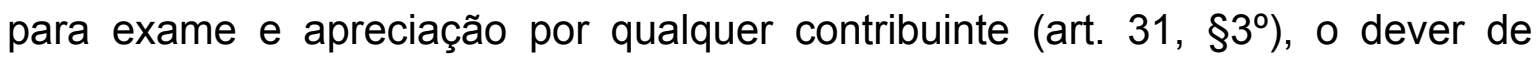
divulgação da arrecadação tributária e dos recursos recebidos de transferência intergovernamentais (art. 162), e a necessidade de elaboração de leis orçamentárias e de divulgação de relatórios resumidos da execução orçamentária (art. 165).

Entretanto, apesar do manancial de dispositivos normativos disciplinando a transparência no ordenamento jurídico brasileiro, e da importância que a ela é atribuída no contexto democrático atual, há pouco aprofundamento teórico sobre o seu significado, seu conteúdo normativo e sua eficácia na dinâmica da atividade financeira do Estado.

A imensidão de problemas relacionados à transparência nas finanças públicas abre espaço para múltiplas formas de abordagem do assunto. É preciso, porém, estabelecer um ponto de partida, delimitando o objeto do estudo a ser desenvolvido nas linhas vindouras: o princípio da transparência no direito financeiro brasileiro. 
Esse corte temático aponta que a investigação toma como base 0 ordenamento vigente (direito positivo), para identificar a transparência como um princípio jurídico, extraído do conjunto de dispositivos normativos que disciplinam a atividade financeira do Estado (direito financeiro).

Tal delimitação metodológica, contudo, não implica desconsiderar a unidade sistêmica do ordenamento jurídico brasileiro, nem as inter-relações existentes entre ramificações do direito. Afinal, "o sistema do direito positivo, expressando uma totalidade normativa, inclui os diversos segmentos da normatividade, porém, não se circunscreve a nenhum deles"3.

A autonomia do direito financeiro é adotada como linha de partida, mas a permeabilidade do sistema jurídico demanda a construção de caminhos teóricos conjuntivos. Destarte, no percurso de construção da tese, o direito financeiro será observado em suas relações interativas com diversos subsistemas normativos, evitando-se dualismos geradores de separações artificiais entre "ramos" ligados por natureza na mesma "árvore" do conhecimento ${ }^{4}$. O estudo analítico do princípio da transparência, com base no todo orgânico da Constituição Financeira $^{5}$, não deve deixar de lado a confluência de normas de múltiplos segmentos jurídicos (e.g., constitucional, administrativo, tributário e econômico) na disciplina das finanças públicas.

Embora a investigação esteja pautada em uma perspectiva dogmática, considerações de ordem zetética ${ }^{6}$, abertas à interdisciplinaridade, serão trazidas em formulações críticas à aplicação do princípio da transparência na atividade financeira do Estado.

\footnotetext{
${ }^{3}$ BORGES, José Souto Maior. Um ensaio interdisciplinar em direito tributário: superação da dogmática. Revista Dialética de Direito Tributário, n. 211, São Paulo, abr./2013, p. 115.

${ }^{4}$ Nas palavras de TOBIAS BARRETO: "O direito é um todo orgânico; as diferentes divisões a que ele se presta não desmancham a harmonia do sistema". BARRETO, Tobias. Estudos de direito. Rio de Janeiro: Laemmert \& C., 1892, p. 36.

${ }^{5}$ Cf. TORRES, Heleno Taveira. Direito constitucional financeiro: teoria da Constituição financeira. São Paulo: Revista dos Tribunais, 2014, p. 69.

${ }^{6}$ A zetética acentua o aspecto indagativo, a abertura de múltiplas dimensões de questionamentos (e.g., de economia política, filosofia, história do direito, dentre infinitas possibilidades), diferentemente da dogmática, de conteúdo diretivo, com premissas voltadas à decisão jurídica. Contudo, "o fenômeno jurídico, com toda a sua complexidade, admite tanto o enfoque zetético, quanto o enfoque dogmático, em sua investigação". FERRAZ JUNIOR, Tercio Sampaio. Introdução ao estudo do direito: técnica, decisão, dominação. 3. ed. São Paulo: Atlas, 2001, p. 43.
} 
Muitos dos problemas de transparência existentes na realidade das finanças públicas no Brasil não decorrem da falta de normas, mas da inadequada aplicação delas. Nesse pormenor, é importante ter em mente que as regras e os princípios do direito financeiro são estabelecidos e aplicados na complexidade do mundo real, onde também coexistem aspectos políticos, econômicos e culturais que influenciam na compreensão e na própria efetividade de comandos jurídicos.

O direito financeiro regula os diversos aspectos da atividade financeira do Estado, mas não a imuniza dos efeitos de outros sistemas sociais, com os quais mantém interdependências e imbricações ${ }^{7}$. Desconsiderar a influência desses sistemas no mundo jurídico, tanto na construção quanto na aplicação das normas, seria desconsiderar a própria realidade social. Ao invés de encerrar a diversidade dos sistemas em noções redutoras e fechadas, a complexidade do tema será tomada como um desafio a ser enfrentado ${ }^{8}$. Um enfrentamento no qual a transdisciplinaridade estará intrinsecamente presente.

A atividade financeira do Estado não se limita ao universo jurídico. Ela também reflete decisões políticas ${ }^{9}$. Para ser completa, necessita abarcar também aspectos sociais e econômicos, considerando a unidade do fenômeno financeiro ${ }^{10}$. Esses fatores condicionantes impactam na elaboração e na aplicação da linguagem do direito financeiro, já que o poder político-financeiro é em grande parte um poder sobre as palavras ${ }^{11}$, isto é, um poder que se exerce por meio de palavras (linguagem do direito financeiro).

De fato, a normatização das finanças públicas é realizada por meio de técnicas de pensamento e ação baseadas em palavras, como instrumentos de construção de uma realidade peculiar ${ }^{12}$. Essa realidade encontra-se em constante

\footnotetext{
${ }^{7}$ Acentua LOURIVAL: "O direito é uma realidade complexa e, por isso, objeto de diversos pontos de vista cognoscitivos". VILANOVA, Lourival. Sobre o conceito de direito. In: VILANOVA, Lourival. Escritos jurídicos e filosóficos. São Paulo: Axis Mundi IBET, 2003, v. 1, p. 32.

${ }^{8}$ Cf. MORIN, Edgar. O método 1: a natureza da natureza. Trad. llana Heineberg. 2. ed. Porto Alegre: Sulina, 2008, p. 185-186.

${ }^{9}$ MARTINS, Maria d'Oliveira. Lições de finanças públicas e direito financeiro. Coimbra: Almedina, 2012, p. 16.

${ }^{10}$ HORVATH, Estevão. Direito financeiro versus direito tributário: uma dicotomia desnecessária e contraproducente. In: HORVATH, Estevão; CONTI, José Maurício; SCAFF, Fernando Facury (Org.). Direito financeiro, econômico e tributário: estudos em homenagem a Regis Fernandes de Oliveira. São Paulo: Quartier Latin, 2014, p. 170.

${ }_{11}^{11}$ BOURDIEU, Pierre. Sur l'État. Paris: Raisons d'agir, 2012, p. 522.

12 Cf. BOURDIEU, Pierre. Sur l'État. Paris: Raisons d'agir, 2012, p. 521.
} 
transformação, a passos cada vez mais velozes. O olhar sobre o direito financeiro precisa igualmente atentar para os reflexos dessas mudanças na contemporaneidade.

A análise do tema proposto exige, de partida, um processo de delimitação semântica, extraindo-se os sentidos em que a palavra "transparência" é utilizada nos dias atuais. Pode-se falar em transparência em outros contextos jurídicos, dissociados do direito financeiro (e.g., a transparência no mercado de capitais ou transparência como objetivo da Política Nacional das Relações de Consumo), ou até mesmo sem qualquer relação com o direito (e.g., a transparência de um material). Mas é o sentido da transparência trazido pelo direito financeiro brasileiro que deverá guiar os passos deste estudo.

O processo de construção do significado da transparência na atualidade demanda uma aproximação conceitual em torno das ideias que ela exprime, além de uma breve análise histórica sobre a evolução e difusão dos fundamentos que the conferem substância, para melhor entender o contexto social em que os textos normativos se inserem.

Uma vez delimitado o sentido da transparência, impõe-se a determinação do seu conteúdo normativo e das suas dimensões de eficácia. Não há efetiva transparência se a própria aplicação do direito financeiro não for transparente, ou se a significação de seus dispositivos for criativamente alterada, ao sabor de necessidades circunstanciais dos governos.

Nessa perspectiva, além da transparência no direito financeiro, deverá ser levada em consideração a transparência do direito financeiro. É essa dupla face da transparência, enquanto princípio, que permite a ampla cognição de todas as etapas da atividade financeira do Estado, incluindo a visibilidade de cada elemento em particular (microvisão), além do seu conjunto (macrovisão). A garantia de visibilidade da atividade financeira do Estado, aliada a mecanismos de controle, tende a limitar os riscos de abusos no exercício do poder políticofinanceiro, fortalecendo a democracia. 
Se a construção de uma sociedade democrática reclama transparência, a perpassar toda a atividade financeira do Estado ${ }^{13}$, mostra-se premente analisar sua dinâmica normativa nas diversas fases do ciclo financeiro: da concepção da política fiscal à execução orçamentária; da arrecadação de receitas públicas à realização de despesas e ao controle do endividamento. Essa dinâmica deverá ser cotejada à luz de critérios de aplicação do princípio da transparência, levando em consideração suas bases axiológicas e desdobramentos normativos (regras e princípios conexos e derivados).

O resultado a ser extraído desse exame é uma teoria sobre o princípio da transparência no direito financeiro brasileiro, edificada com base na Constituição da República, que o projeta como elemento essencial às expectativas de cumprimento da ordem constitucional, de confiança na legitimidade do exercício do poder financeiro, e de controle da atividade financeira estatal.

\section{MOTIVOS CONDUTORES}

São muitas as razões que justificam o exame da transparência como princípio do direito financeiro brasileiro, a começar pela sua já destacada atualidade. A transparência passou a ocupar posição proeminente na regulação jurídica das finanças públicas ao longo dos últimos anos, despontando como elemento condutor da atividade financeira do Estado Democrático de Direito.

Contudo, apesar da importância conquistada pela transparência na democracia brasileira contemporânea, sua compreensão pelos Poderes constituídos, nas diferentes esferas de governo, tem suscitado inúmeras controvérsias. Embora frequentemente seja relacionada a concepções de boa governança financeira, controle social da gestão pública e combate ao uso indevido de recursos públicos, dúvidas ainda pairam a respeito da sua significação jurídica. O que, afinal, se entende por transparência? Qual a sua

${ }^{13}$ TORRES, Heleno Taveira. Direito constitucional financeiro: teoria da Constituição financeira. São Paulo: Revista dos Tribunais, 2014, p. 30. 
estrutura normativa? Em que se fundamenta? Quais os seus aspectos? Que estado de coisas busca realizar? De que maneira? Quais os seus limites e campos de aplicabilidade na dinâmica da atividade financeira do Estado?

A densa teia de questionamentos relacionados ao princípio da transparência contrapõe-se a um escasso aprofundamento teórico sobre sua estrutura normativa. Muito se fala da sua relevância, mas pouco se conhece sobre sua origem, significação, conteúdo e alcance. A tendência doutrinária de considerar a transparência como algo autoevidente, de valor intrínseco, acaba contribuindo para o esquecimento de questionamentos analíticos sobre seus aspectos essenciais.

Conquanto extremamente atual, a transparência não é um assunto inteiramente novo. Muitas construções teóricas sobre a visibilidade da esfera pública e segredos de Estado, em diferentes contextos históricos, contribuíram para a formação do arcabouço jurídico que atualmente lastreia a ideia de máxima difusão de informações de interesse público e controle do exercício do poder ${ }^{14}$. Essas contribuições, no entanto, carecem de análises sistematizadoras que as relacionem, a partir de um fio condutor, com a dinâmica da atividade financeira do Estado Democrático de Direito brasileiro.

Uma das dificuldades de encadeamento do assunto, em linguagem no descritiva do direito financeiro, é de ordem conceitual. Há uma pluralidade de significações do vocábulo "transparência". Muitas vezes confundem-se as perspectivas contábil, orçamentária e de divulgação de informações em meios eletrônicos de acesso público ${ }^{15}$. Na terminologia jurídica, tal palavra tem sido tomada em diferentes usos linguísticos, em textura bastante aberta, com substancial vagueza e ambiguidade ${ }^{16}$. Por vezes, ela é adotada em referência à

\footnotetext{
${ }^{14}$ Cf. KANT, Immanuel. À paz perpétua. Trad. Marco Zingano. Porto Alegre: L\&PM Pocket, 2011; ARENDT, Hannah. The human condition. Introduction by Margaret Canovan. 2. ed. Chicago: University of Chicago Press, 1998; HABERMAS, Jüngen. Mudança estrutural na esfera pública: investigações sobre uma categoria da sociedade burguesa. Trad. Denilson Luís Werle. São Paulo: Unesp, 2014; BOBBIO, Norberto. Il futuro della democrazia. Torino: Einaudi, 1995.

15 RICCIO, Edson Luiz; TEIXEIRA, Marco Antonio Carvalho; ZUCCOLOTTO, Robson. Transparência: reposicionando o debate. Revista Contemporânea de Contabilidade, Florianópolis, v. 12, n. 25, jan./abr. 2015, p. 139.

${ }^{16}$ Sobre os usos da linguagem e as dificuldades da comunicação jurídica relacionadas à textura aberta, à vagueza e à ambiguidade: cf. CARRIÓ, Genaro R. Notas sobre derecho y lenguaje. 3. ed. Buenos Aires: Abeledo-Perrot,1986, p. 18-36.
} 
publicidade dos atos da Administração Pública em geral ${ }^{17}$; outras vezes, em sentido mais específico, concernente ao processo orçamentário e à acessibilidade das informações sobre sua execução (transparência "orçamentária") ${ }^{18}$. Ademais, no campo do direito tributário, utiliza-se expressão "transparência fiscal internacional" para exprimir o regime especial de tributação de empresas controladas e coligadas (CFCs - "Controlled Foreign Companies") ${ }^{19}$.

As definições do conceito de transparência, na doutrina do direito financeiro, apresentam variados enfoques: (i) como "princípio de gestão", destinado a "franquear ao público o acesso a informações relativas às atividades financeiras do Estado e deflagrar, de forma clara e previamente estabelecida, os procedimentos necessários à divulgação dessas informações" 20 ; (ii) como "elemento de governabilidade do Estado, passando a constituir-se também em princípio orçamentário"21; (iii) como "abertura à sociedade sobre a estrutura e as funções do governo, os objetivos da política fiscal e as contas e metas do setor público"22; (iv) como "visibilidade" decorrente da participação cidadão na gestão

\footnotetext{
${ }^{17}$ Celso Antônio Bandeira de Mello menciona o dever da Administração Pública de manter "plena transparência em seus comportamentos" como consagração do princípio da publicidade (cf. MELLO, Celso Antônio Bandeira de. Curso de direito administrativo. 30 ed. São Paulo: Malheiros, 2013, p. 117). Na mesma linha, JOSÉ DOS SANTOS CARVALHO FILHO alude à transparência das condutas da Administração, ao explicar o conceito do princípio da publicidade (cf. CARVALHO FILHO, José dos Santos. Manual de direito administrativo. 30 ed. São Paulo: Atlas, 2016, p. 78).

${ }^{18} \mathrm{Cf}$. ALVES, Marcus Vinícius Chevitarese. Transparência orçamentária efetiva e internet: um estudo a partir dos portais eletrônicos de orçamento da Câmara dos Deputados e do Senado Federal. Disponível em: <http://bd.camara.gov.br/bd/handle/bdcamara/5644>. Acesso em: 19 jul. 2016; PIRES, Valdemir Aparecido. Transparência orçamentária municipal via Internet (TOM Web) no contexto do revigoramento democrático e republicano: uma proposta. III Prêmio SOF de monografias. Disponível a partir de: <http://www.orcamentofederal.gov.br/educacaoorcamentaria>. Acesso em: 19 jul. 2016.

19 "Na legislação tributária estrangeira, o regime de tributação das CFCs - que em alguns países é conhecido como regime da transparência fiscal internacional - é aquele em que os lucros auferidos por determinadas pessoas jurídicas, sediadas em um país, passem a ser tributados diretamente na pessoa de seus sócios, residentes em outro país, como se estes últimos os tivessem auferidos diretamente. É nesse sentido que a pessoa jurídica sediada no exterior, do ponto de vista da legislação fiscal do país de residência dos sócios, é chamada de transparente." BIANCO, João Francisco. Transparência fiscal internacional. São Paulo: Dialética, 2007, p. 20-21. Tal dimensão semântica, específica do direito tributário, não integra o objeto da nossa investigação.

${ }^{20}$ CRUZ, Flávio da (coord.). Lei de responsabilidade fiscal comentada. São Paulo: Atlas, 2001, p. 142.

${ }^{21}$ MILESKI, Helio Saul. A transparência da Administração Pública pós-moderna e o novo regime de responsabilidade fiscal. Interesse Público - IP, Belo Horizonte, ano 12, n. 62, jul./ago. 2010.

${ }^{22}$ RUBINSTEIN, Flávio. Notas sobre a transparência fiscal no direito financeiro. In: CONTI, José Mauricio e SCAFF, Fernando Facury (Coord.). Orçamentos públicos e direito financeiro. São Paulo: Revista dos Tribunais, 2011, p. 871.
} 
pública $^{23}$; ou (v) como "fenômeno que demanda um esforço, por parte da administração pública, no sentido de disponibilizar ao público, em tempo adequado, dados e informações facilmente mensuráveis e acessíveis" ${ }^{24}$, relativas à atividade financeira das pessoas jurídicas que compõem o Estado.

A jurisprudência do Supremo Tribunal Federal tampouco apresenta uniformidade conceitual sobre a normatividade da transparência, que já foi entendida como "vertente específica" ${ }^{25}$ do princípio constitucional da publicidade da administração pública (art. 37, caput, da CF/88), como "dever" ${ }^{26}$ decorrente desse princípio, e também como "princípio"27.

Essa profusão conceitual, a gerar ambiguidade, vagueza e incerteza sobre o significado, o conteúdo e o alcance do princípio da transparência no direito financeiro brasileiro, já justificaria a necessidade de melhor examinar o tema. Mas a ela se somam outros motivos igualmente relevantes: (i) a falta de transparência, no plano fático, que ainda se observa em relação a alguns aspectos das finanças públicas nos diversos níveis de governo e poderes constituídos; (ii) paradoxalmente, os problemas relacionados à crescente ampliação do campo de aplicação do princípio da transparência; (iii) as dificuldades decorrentes da carência e da desordenação de critérios para a tomada de decisão em casos difíceis (hard cases), envolvendo direitos fundamentais.

No tocante à falta de transparência, constata-se discrepâncias quanto à aplicação desse princípio do direito financeiro, por parte dos entes federados e dos poderes constituídos ${ }^{28}$. Carências de informações básicas, medidas de

${ }^{23}$ ASSONI FILHO, Sérgio. Sérgio. Transparência fiscal e democracia. Porto Alegre: Núria Fabris, 2009, p. 15.

${ }^{24}$ HABER NETO, Michel. Transparência fiscal e sigilo tributário. Tese (Doutorado em Direito). Faculdade de Direito da Universidade de São Paulo, 2015, p. 77.

${ }^{25}$ BRASIL. Supremo Tribunal Federal. ADI 2198, Rel. Min. Dias Toffoli, Tribunal Pleno, julgado em 11/04/2013, DJe de 16/08/2013. No mesmo sentido: ADI 2444, Rel. Min. Dias Toffoli, Tribunal Pleno, julgado em 06/11/2014, DJe de 30/01/2015.

${ }^{26}$ BRASIL. Supremo Tribunal Federal. ADI 2361, Rel. Min. Marco Aurélio, Tribunal Pleno, DJe de $23 / 10 / 2014$.

${ }^{27}$ BRASIL. Supremo Tribunal Federal. RE 766390 AgR, Rel. Min. Ricardo Lewandowski, Segunda Turma, julgado em 24/06/2014, DJe de 14/08/2014.

${ }^{28}$ No segundo semestre de 2015, o Ministério Público Federal realizou avaliação dos portais de transparência dos Estados e Municípios brasileiros, analisando itens como a possibilidade de envio de pedidos de informação por meio eletrônico e a disponibilização de dados sobre a atividade financeira de cada ente político (receitas, despesas, prestação de contas do ano anterior 
"contabilidade criativa"29 ou mesmo a ausência de padrões contábeis uniformes entre os diversos órgãos e níveis de governo acabam gerando variados graus de opacidade nas finanças públicas. O sistema contábil, pressuposto para assegurar transparência em relação aos recursos arrecadados e despendidos ${ }^{30}$, em alguns aspectos, acaba não refletindo a realidade financeira de cada ente federado. $A$ mesma informação chega a assumir valores díspares, evidenciando problemas de harmonização e de convergência entre os instrumentos de controle ${ }^{31}$. Critica-se, com razão, a insinceridade orçamentária ${ }^{32}$ e as manipulações de informações financeiras disponibilizadas nas esferas federal, estadual, e municipal.

De outra banda, a disseminação da transparência, nos últimos anos, tem desencadeado o surgimento de múltiplos problemas interpretativos. As previsões normativas da LRF e da Lei n. 12.527/2011 contribuíram para densificar o princípio e regular o direito fundamental de acesso à informação (art. $5^{\circ}$, XXXIII), mas a sua leitura literal não oferece respostas para diversos questionamentos atuais ${ }^{33}$. Como compatibilizar a acessibilidade informacional com a necessidade de proteção à segurança da sociedade e do Estado? É

e relatório de gestão fiscal). As irregularidades constatadas ensejaram o encaminhamento de mais de 3 mil recomendações a Estados e Municípios, indicando pontos a serem corrigidos, e a propositura de mais de 2 mil ações civis públicas em todo o País. No caso de Municípios que em 2016 ainda não haviam implantado portais de transparência, além de ações civis públicas foram ajuizadas ações de improbidade administrativa contra os respectivos prefeitos, emitidas recomendações de suspensão de repasses de transferências voluntárias, e formuladas representações pela prática de crime de responsabilidade. In: BRASIL. Ministério Público Federal. Ranking Nacional da Transparência. Disponivel a partir de: <http://combateacorrupcao.mpf.mp.br>. Acesso em: 14 jul. 2016. O número expressivo de recomendações e ACPs indica a existência de sérios problemas na aplicação do princípio da transparência no Brasil.

${ }^{29}$ Termo utilizado em alusão a técnicas de contabilidade adotadas com a finalidade de aparentar uma melhor situação fiscal das contas públicas.

${ }^{30} \mathrm{Cf}$. BRANCASI, Antonio. La contabilità come fonte di conoscibilità dei dati e precondizione di trasparenza. In: MERLONI, Francesco (Org.). La trasparenza amministrativa. Milano: Giuffré, 2008, p. 72.

${ }^{31}$ ALVES, Diego Prandino. Divergências entre instrumentos de controle social no Brasil: uma comparação entre dados do Portal da Transparência, dos relatórios de gestão anuais de entidades públicas e do Relatório do Tribunal de Contas da União sobre as Contas da República. Fórum de Contratação e Gestão Pública - FCGP, Belo Horizonte, ano 10, n. 114, p. 64-79, jun. 2011.

${ }_{32}$ Cf. PANCRAZI, Laurent. Principe de sincérité budgétaire. Paris: L'Harmattan, 2012.

${ }^{33}$ Destacou o Ministro DIAS TOFFOLI na análise da repercussão geral do RE 865.401: "Essa previsão constitucional, por sua vagueza e pela amplitude do poder conferido ao agente público, conduz frequentemente a divergências de interpretação e conflitos de interesses, os quais, não raro, acabam sendo decididos apenas nos tribunais. Embora a Lei de Acesso à Informação, editada como regulamentação do art. 5o, inciso XXXIII, da CF, tenha trazido luz à questão e servido de guia para a efetivação do direito fundamental versado, é certo que não bastou para a total pacificação do tema". BRASIL. Supremo Tribunal Federal. RE 865401 RG, Rel. Min. Dias Toffoli, julgado em 14/08/2015, Acórdão Eletrônico, DJe de 08/10/2015. 
legítimo restringir o acesso a informações sobre a atividade financeira estatal? Em que medida? Com base em quais critérios?

O segredo sempre esteve presente na vida do ser humano, e consequentemente na realidade por ele transformada. Segredos também permeiam aspectos da atividade do Estado, inclusive de caráter financeiro. Contudo, quando o sigilo em torno de elementos das finanças públicas é cabível em um regime democrático?

Se, por um lado, a racionalidade intrínseca aos governos implica alguma dose de segredos (quem governa precisa conhecer a realidade do Estado, mas em algumas situações esse conhecimento só é um instrumento de governo contanto que não seja imediatamente divulgado ${ }^{34}$ ), por outro, o componente democrático clama pela visibilidade do exercício do poder financeiro.

Nesse ponto, dualismos históricos afloram em tensão: luminosidade e escuridão; aparição e ocultação; conhecimento e ignorância. Viabilizar a passagem da luz para aclarar os elementos que compõem a complexa realidade das finanças públicas, em sentido metafórico, é o que faz da transparência uma propriedade vital para o ambiente democrático e republicano ${ }^{35}$. Uma propriedade que instrumentaliza a compreensão das políticas públicas pelos cidadãos $^{36} \mathrm{e}$ facilita o controle da atividade administrativa ${ }^{37}$. Com efeito, potencializa melhorias na qualidade da gestão, aproximando-a da sociedade, que passa a contribuir de maneira mais ativa no combate a medidas nefastas ao interesse coletivo, como o aumento de despesas extravagantes e o desvio de verbas. Para tanto, o acesso a

\footnotetext{
${ }^{34}$ FOUCAULT, Michel. Segurança, território, população: curso dado no Collège de France (19771978). Trad. Eduardo Brandão. São Paulo: Martins Fontes, 2008, p. 363-367.

${ }^{35}$ Aduz EMILIO GuICHOT: "Si la información es poder y la democracia es el poder del pueblo en el gobierno de un Estado, es necessario poner la información a disposición de los ciudadanos ya que con suficientes ojos pendientes, qualquier fallo puede solventarse, incluidos los casos de abusos, arbitrariedades y corrupción, ya que, siguiendo una imagen que ha hecho célebre, la luz del sol es el mejor de los desinfectantes" GUICHOT, Emilio. El sentido, el contexto y la tramitación de la ley de transparencia, acceso a la información pública y buen gobierno. In: GUICHOT, Emilio (Coord.). Transparencia, acceso a la información pública y buen gobierno: estudio de la ley 19/2013, de 9 de diciembre. Madrid: Tecnos, 2014.

${ }^{36}$ HOMERCHER, Evandro T.; BERGUE, Sandro Trescastro. Políticas públicas e transparência: reflexões multidisciplinares. Interesse Público - IP, São Paulo, ano 13, n. 68, p. 405-422, jul./ago. 2011.

${ }^{37}$ MEDAUAR, Odete. Controle da administração pública. 2. ed. São Paulo: Revista dos Tribunais, 2012, p. 176.
} 
informações sobre a atividade financeira do Estado deve ser o mais amplo possível. Mas isso não significa que deva ser irrestrito.

É intuitivo que o segredo nas finanças públicas pode abrir margens para desvirtuamentos de gastos ${ }^{38}$, criando ambientes opacos propícios a práticas deletérias. No entanto, o acesso indiscriminado a quaisquer informações financeiras também pode ocasionar riscos à soberania e à segurança do próprio Estado. Daí a possibilidade de limitações à transparência, por meio de procedimentos de controle do sigilo.

Com efeito, o debate sobre transparência é também uma batalha de argumentos sobre como as informações devem ser disponibilizadas e quando o segredo pode servir melhor ao interesse público ${ }^{39}$. Compreender esses argumentos é fundamental para a tomada de posições racionalmente justificadas, que conduzam a soluções adequadas para os conflitos de interesses relacionados ao tema.

Todavia, ainda não há uniformidade nem clareza suficiente no tratamento de muitas das chamadas "despesas sigilosas", realizadas em nome da segurança da sociedade e do Estado ${ }^{40}$. Paira semelhante nebulosidade sobre o alcance da garantia constitucional de inviolabilidade da intimidade e da vida privada, notadamente no que diz respeito a operações financeiras com recursos públicos. Informações de empréstimos privados subsidiados com recursos públicos podem ser mantidas sob sigilo? Pessoas jurídicas de direito privado beneficiadas com transferências de recursos públicos precisam prestar contas à sociedade sobre os respectivos valores? Quais as fronteiras entre os "jardins" privados e a "praça" pública ${ }^{41}$ ?

\footnotetext{
${ }^{38}$ Nesse sentido, alertava VEIGA FILHO: "Segredo ou mysterio, em materia de finanças publicas, é prenuncio do esbanjamento". In: VEIGA FILHO, João Pedro da. Manual da sciencia das finanças. 4. ed. São Paulo: Monteiro Lobato, 1923, p. 34.

${ }^{39}$ FLORINI, Ann. The battle over transparency. In: FLORINI, Ann (Ed.). The right to know: transparency for an open world. New York: Columbia University Press, 2007, p. 1.

${ }^{40}$ SCAFF, Fernando Facury. Direitos fundamentais e orçamento: despesas sigilosas e o direito à verdade. In: CONTI, José Mauricio e SCAFF, Fernando Facury (Coord.). Orçamentos públicos e direito financeiro. São Paulo: Revista dos Tribunais, 2011, p. 222/229.

${ }^{41}$ A metáfora do jardim e da praça é utilizada por NELSON SALDANHA para ilustrar a contraposição e as relações entre a vida pública (simbolizada pela praça) e a vida privada (simbolizada pelo jardim). Cf. SALDANHA, Nelson. O jardim e a praça: o privado e o público na vida social e histórica. São Paulo: EDUSP, 1993.
} 
$\mathrm{Na}$ "praça financeira" 42 do Estado Democrático de Direito, o conhecimento dos seus elementos, inclusive dos "bancos" que a guarnecem, deve proporcionar confiança à sociedade. Nela não devem existir "jardins secretos", impenetráveis aos cidadãos, ou redutos mal iluminados e inseguros. Restrições de acesso pontuais, legalmente fundadas e devidamente motivadas, por determinado período de tempo, são admitidas excepcionalmente, quando essenciais à preservação da segurança da própria sociedade e do espaço público.

Cotidianamente, as relações humanas se perfazem na mistura de luz e escuridão, na luminosidade temperada, na sombra clara ${ }^{43}$, no claro-escuro $\left(\right.$ chiaroscuro $\left.^{44}\right)$. Porém, quando se trata de relações envolvendo a coisa pública (res publica), em um regime democrático, a zona de luminosidade deve ser preponderante, apenas se justificando a penumbra em situações excepcionais. $O$ fortalecimento da democracia e a facilidade de acesso a informações na era do conhecimento apontam para ambientes públicos cada vez mais iluminados.

É preciso, porém, apontar formas de lidar com essas dicotomias no direito financeiro, por meio de lentes que permitam enxergar, em perspectiva dinâmica e pluridimensional, os novos caminhos abertos pela transparência. Caminhos por vezes labirínticos, a exigir uma análise cuidadosa do mapa dos dispositivos jurídicos vigentes, cotejados com perspectivas doutrinárias e jurisprudenciais.

O excesso de informações que caracteriza a atual sociedade em rede $^{45}$, potencializado pelas novas tecnologias, é também um fator problemático. O aumento da transparência do setor público gera mais volume de informações, e a ampliação contínua desse leque informacional traz consigo a dificuldade de

\footnotetext{
${ }^{42}$ SCAFF, Fernando Facury. $O$ jardim e a praça ou a dignidade da pessoa humana e o direito tributário e financeiro. In: TORRES, Heleno Taveira (Org.). Direito e poder nas instituições do público e do privado contemporâneos: estudos em homenagem a Nelson Saldanha. Barueri: Manole, 2005, p. 543-557.

${ }^{43}$ "À la vérité, jamais n'a existé ni le tout clair ni le tout obscur. C'est le mélange de la lumière et de l'ombre qui est notre climat. À cette lumière tempérée, à cette ombre claire, il faut nous accommoder". GUITTON, Jean. Le clair et l'obscur. Paris: Éditions Aubier, 1964, p. 11.

${ }^{44}$ Expressão italiana utilizada para designar a mistura entre luz e sombra, empregada na pintura renascentista e barroca, por artistas como Caravaggio.

${ }^{45}$ Cf. CASTELLS, Manuel. A era da informação: economia, sociedade e cultura, v. 1: a sociedade em rede. 9. ed. Trad. Roneide Venâncio Majer. São Paulo: Paz e Terra, 2006.
} 
extração e depuração daquilo que é útil. O combate à obscuridade das finanças públicas simplesmente pela via da divulgação irrefletida, sem cuidados de tratamento das informações, pode contraditoriamente contribuir para uma maior opacificação. A dificuldade de cognoscibilidade em meio ao turbilhão de informações disponibilizadas relaciona-se com o incremento do sentimento de insegurança, que pode acarretar riscos: "quanto maior é a quantidade de informação, tanto maior também é aquilo que precisa ser previamente considerado e avaliado" ${ }^{46}$.

Assim, argumenta-se que é insuficiente a mera possibilidade de acesso a informações, sendo imprescindível atentar para a sua inteligibilidade, vale dizer, para a simplicidade, a clareza e o didatismo. Mas, na busca dessa tríade, muitas vezes é preciso deixar de lado determinados aspectos do objeto do conhecimento em sua amplitude real. Trata-se de mais um paradoxo da transparência, a anunciar outros questionamentos: que tipo de informação pode ser ocultada? Em qual extensão? Há limites de tempo para a disponibilidade de acesso?

Em algumas hipóteses, ocultações adjacentes podem contribuir para a cognição de informações centrais mais relevantes; noutras vezes, ocultar informações estatais estratégicas durante certo tempo pode ser fundamental para o interesse da própria sociedade. Entretanto, quando inexistem motivos fundados para ocultações, e mesmo assim elas ocorrem na aplicação do direito financeiro, de maneira direta (recusa expressa da Administração) ou indireta (postergação na divulgação), a transparência é colocada em uma encruzilhada. Como assegurar a sua efetividade?

A temporalidade é um aspecto relevante a ser levado em consideração. O dinamismo das trocas financeiras no mundo globalizado não se compatibiliza com a postergação desmedida da divulgação de informações de interesse público. O imediatismo é marcante na sociedade atual. Exigências de instantaneidade e rapidez definem o futuro no mercado financeiro - onde se realiza parcela expressiva da atividade financeira do Estado (operações de

\footnotetext{
${ }^{46}$ ÁVILA, Humberto. Segurança jurídica: entre permanência, mudança e realização no direito tributário. São Paulo: Malheiros, 2011, p. 40.
} 
crédito, câmbio, etc.), e demoras nesse fluxo podem ocasionar enormes prejuízos - públicos e privados.

Os avanços das novas tecnologias de transmissão e armazenamento de informações tornaram possível a transparência em tempo real (real-time transparency $)^{47}$. A informação financeira do Estado passa a ser disponível em rede, acessível a partir de qualquer lugar (desprendidas, na virtualidade, de um "aqui e agora" ${ }^{48}$ ), e submetida ao crivo da população e da mídia, articuladas em redes sociais. A transparência, cada vez mais, reflete-se na eficiência dos mecanismos de divulgação de informações ${ }^{49}$ e na capacidade do Estado de manter-se atualizado no mundo tecnológico.

Como um processo em contínua construção na dinâmica da atividade financeira estatal, a transparência vem sendo aperfeiçoada com a evolução de novas tecnologias. Mas a tecnologia, embora seja uma ferramenta indispensável, não garante por si só a efetividade das normas jurídicas, isto é, a observância das prescrições estabelecidas pelo direito financeiro, na sua aplicação in concreto. Daí a importância de compreender o conteúdo e o alcance das disposições normativas que disciplinam a atuação do Estado no que tange às tecnologias de informação a serviço da sociedade.

O reconhecimento principiológico da transparência é apenas um dos passos na rota de melhoria da realidade das finanças públicas no Brasil, e das condições para que as pessoas possam exercer plenamente suas potencialidades.

Como resultado de uma longa história permeada por uma preocupação fundamental com a transparência financeira, ligada à qualidade dos laços sociais,

\footnotetext{
${ }^{47}$ BIRCHALL, Clare. Introduction to 'secrecy and transparency': the politics of opacity and opennness. Theory, Culture \& Society, v. 28 n. 7-8, december 2011.

${ }^{48}$ Cf. LÉVY, Pierre. O que é o virtual? Trad. Paulo Neves. São Paulo: 34, 1996, p. 58.

49 As novas tecnologias contribuíram para a aceleração do movimento de difusão da transparência, como propulsora da democracia em uma nova Era (da Informação). Nesse sentido: "(...) la transparence a envahi les sphères de la politique, du droit, de l'économie, des finances et des médias. L'apparition des nouvelles Technologies n'a fait qu'accélérer le mouvement, faisant naître l'espoir d'une nouvelle forme de gouvernement fondée sur une véritable gouvernance citoyenne qui propulsera la démocratie dans un nouvel âge". In: ZOLLER, Elisabeth; GUGLIELMI, Gilles-J. (Dir.). Transparence, démocratie et gouvernance citoyenne. Paris: Editions PanthéonAssas, 2014.
} 
as finanças públicas são um instrumento para a análise da própria sociedade, ensejando uma leitura de como ela se organiza ${ }^{50}$.

Examinar a transparência no direito financeiro brasileiro implica conhecer a forma de organização da sociedade, integrando a dogmática constitucional com dados sócio-políticos ${ }^{51}$. As instituições políticas influenciam o comportamento dos agentes econômicos e determinam o sucesso ou o fracasso das nações ${ }^{52}$. As influências dos mecanismos de transparência, nesse sentido, merecem ser consideradas.

É necessário, no entanto, cautela. O perigo de tomar-se a transparência como remédio para quaisquer males financeiros do Estado contemporâneo é reduzi-la a um mote retórico ou simples expressão de persuasão argumentativa, deixando de lado aspectos importantes da sua dimensão normativa. Tais aspectos normativos guardam estreitos laços com a cidadania, a participação popular e o controle social em questões fiscais ${ }^{53}$, bem como com a própria segurança jurídica ${ }^{54}$ da atividade financeira estatal - na medida em que visam a aumentar o grau de cognoscibilidade, confiabilidade e calculabilidade na criação e aplicação do direito financeiro ${ }^{55}$.

A cidadania e a participação popular são núcleos essenciais do Estado Democrático de Direito brasileiro, que devem orientar a hermenêutica da Constituição Financeira. A força normativa da Constituição não depende apenas

\footnotetext{
50 "En effet, parce qu'elles sont fondamentalement d'essence politique, qu'elles sont issues d'une longue histoire traversée notamment par une préoccupation fondamentale, celle de la transparence financière, et que cette dernière a toujours été systématiquement liée à la qualité $d u$ lien social, les finances publiques se présentent comme un instrument privilégié d'analyse et de création des sociétés politiquement organisées: non seulement elles permettent d'en lire les mécanismes mais eles donnent naissance aussi à des conceptions et pratiques nouvelles." BOUVIER, Michel; ESCLASSAN, Marie-Christine; LASSALE, Jean-Pierre. Finances publiques. 11. ed. Paris: L.G.D.J, 2012, p. 9.

${ }^{51}$ Cf. VERDÚ, Pablo Lucas. La Constitución en la encrucijada (palingenesia iuris politici). Pensamiento Constitucional, año IV, n. 4, p. 70.

${ }^{52}$ ACEMOGLU, Daron; ROBINSON, James A. Why naitons fail: the origins of power, prosperity and poverty. New York: Crown Business, 2012, p. 43.

${ }^{53}$ Cf. FUNG, Archon; KHAGRAM, Sanjeev; RENZIO, Paolo de. Overview and synthesis: the political economy of fiscal transparency, participation and accountability around the world. In: FUNG, Archon; KHAGRAM, Sanjeev; RENZIO, Paolo de. (Ed.). Open budgets: the political economy of transparency, participation and accountability. Washington, D.C.: Brookings Institution Press, 2013, p. 3.

${ }^{54}$ Cf. TORRES, Heleno Taveira. Direito constitucional tributário e segurança juridica: metódica da segurança juridical do sistema constitucional tributário. São Paulo: Revista dos Tribunais, 2011.

${ }^{55}$ Cf. ÁVILA, Humberto. Segurança jurídica: entre permanência, mudança e realização no direito tributário. São Paulo: Malheiros, 2011.
} 
do seu conteúdo, mas também de sua práxis ${ }^{56}$, isto é, da forma como são interpretados e concretizados os seus dispositivos. Nesse processo, a plenitude normativa deve ser permanentemente perseguida, com vistas à máxima eficácia dos princípios constitucionais, compreendendo-se a Constituição como um projeto nacional de desenvolvimento ${ }^{57}$, que se realiza pela efetivação das suas previsões normativas.

$\mathrm{Na}$ dinâmica de efetivação constitucional, o Poder Judiciário desempenha papel proeminente. Diversas controvérsias jurisprudenciais atestam a importância adquirida pela transparência na atualidade, especialmente no âmbito do direito financeiro ${ }^{58}$. A necessidade de identificação dos argumentos utilizados pelos Tribunais na aplicação do princípio da transparência, especialmente quando envolve a ponderação com outros princípios e direitos contrapostos, também justifica o escopo deste trabalho.

A vagueza conceitual e a falta de uniformidade na estruturação do conteúdo e do alcance da transparência igualmente têm sido refletidas nessas celeumas judiciais. Na maioria das vezes, pouco se aprofunda na análise da sua normatividade.

Como a intensidade da força normativa do princípio da transparência, no plano pragmático, reflete a compreensão dos aplicadores do direito financeiro sobre o conteúdo das relações entre diversos dispositivos que tratam direta ou indiretamente da matéria, a ordenação teórica desses aspectos pode contribuir para ganhos de eficácia social (efetividade) do princípio.

Mostra-se, pois, pertinente a análise da transparência como princípio jurídico disciplinador da atividade financeira do Estado, a partir de um método que

\footnotetext{
${ }^{56}$ HESSE, Konrad. A força normativa da Constituição. Trad. Gilmar Ferreira Mendes. Porto Alegre: Fabris, 1991, p. 21.

${ }^{57}$ Cf. BERCOVICI, Gilberto. Poder Constituinte do povo no Brasil: um roteiro de pesquisa sobre a crise constituinte. Lua Nova, São Paulo, n. 88, p. 318-319, 2013.

${ }^{58}$ Dentre vários julgados do Supremo Tribunal Federal, analisados neste trabalho, podem ser destacados: SS 3902-AgR-segundo, DJe de 30/09/2011; ADI 2198, DJe de 19/08/2013; ADI 2361, DJe de 23/10/2014; ADI 2444, DJe de 30/01/2015; MS 28178, DJe de 07/05/2015; RE 673707, DJe de 29/09/2015 (todos do Tribunal Pleno).
} 
Ihe reduza a vagueza semântica e amplie a sua aplicabilidade concreta. Poucos estudos tratam disso no direito financeiro brasileiro ${ }^{59}$.

A miríade de perguntas, ainda não respondidas, sobre os critérios de aplicação do princípio da transparência e sua concretização a partir da Constituição Financeira, provoca a necessidade de um enfrentamento teórico aprofundado sobre o tema. É o que propõe este trabalho: a análise das origens, dos fundamentos, dos elementos estruturais e da eficácia do princípio da transparência na atividade financeira do Estado Democrático de Direito brasileiro.

\section{ROTEIRO}

Apontados os motivos que justificam a análise do princípio da transparência no direito financeiro brasileiro, a fim de reduzir-lhe o grau de vagueza e indeterminação, potencializando a sua aplicação na dinâmica da atividade financeira estatal, cumpre delinear o roteiro do trabalho, estruturado em três partes.

Na primeira parte, um rápido esboço genealógico-semântico. Como o estudo parte da premissa de que não há uma compreensão precisa do significado e da estrutura normativa da transparência, busca-se inicialmente uma aproximação conceitual. Para estabelecer uma definição do seu conceito, serão resgatadas as origens históricas da ideia de transparência e tracejada sua evolução no campo das finanças públicas até os dias atuais. Em sequência, serão examinadas suas diferentes dimensões semânticas.

Delineados os campos de significação da transparência, na segunda parte deverão ser fixados os seus alicerces. Nesse interlúdio, mais lentamente,

\footnotetext{
${ }^{59}$ Destacam-se as seguintes contribuições doutrinárias sobre o princípio da transparência no âmbito do direito financeiro brasileiro: ASSONI FILHO, Sérgio. Sérgio. Transparência fiscal e democracia. Porto Alegre: Núria Fabris, 2009; RUBINSTEIN, Flávio. Notas sobre a transparência fiscal no direito financeiro. In: CONTI, José Mauricio e SCAFF, Fernando Facury (Coord.). Orçamentos públicos e direito financeiro. São Paulo: Revista dos Tribunais, 2011; CORREIA NETO, Celso de Barros e MENDES, Gilmar Ferreira. Transparência fiscal. In: MARTINS, Ives Gandra da Silva; MENDES, Gilmar Ferreira e NASCIMENTO, Carlos Valder do (Org.). Tratado de direito financeiro. São Paulo: Saraiva, 2013, v. 1; e HABER NETO, Michel. Transparência fiscal e sigilo tributário. Tese (Doutorado em Direito). Faculdade de Direito da Universidade de São Paulo, 2015.
} 
serão examinadas as bases axiológicas da atividade financeira do Estado Democrático de Direito brasileiro, e investigados os fundamentos constitucionais a partir dos quais a transparência se estrutura normativamente como princípio. Os desdobramentos infraconstitucionais desse arcabouço jurídico, em normas gerais de direito financeiro ou regras e princípios conexos, serão também detalhados nessa segunda parte. Compreendida a fundamentação do princípio, dissecaremos o seu conteúdo normativo, vale dizer, os seus aspectos materiais, espaciais, temporais, funcionais, e subjetivos, além das suas garantias constitucionais.

$\mathrm{Na}$ terceira parte, quando já delimitados os aspectos semânticos e estruturais, o princípio da transparência será observado sob perspectiva pragmática. Nessa etapa, será analisada, no plano da eficácia, a densificação do princípio nas diferentes etapas da atividade financeira do Estado Democrático de Direito brasileiro.

Em síntese: primeiramente, um enfoque conceitual, seguido de uma perspectiva relacional; posteriormente, uma abordagem da efetividade dos mecanismos jurídicos de transparência estabelecidos pelo direito financeiro.

Impõe-se, assim, a utilização de um processo de construção semântica e ordenação estrutural da transparência como princípio jurídico, a partir da análise do direito positivo brasileiro. Conjugam-se relações semânticas (o que o texto normativo significa), sintáticas (relações internormativas) e pragmáticas (efeitos), analisando-se o modo como a Administração Pública e o Poder Judiciário compreendem e aplicam os dispositivos normativos que disciplinam a transparência na atividade financeira do Estado. $O$ foco analítico jurídico não afasta pontos de vista filosóficos, históricos e econômicos. Tais perspectivas, porém, serão trazidas em complementariedade interdisciplinar ao viés dogmático da transparência como princípio do direito financeiro brasileiro.

Embora se trate de um estudo de direito financeiro, adota-se uma compreensão do ordenamento jurídico como sistema, organizado logicamente ${ }^{60}$.

\footnotetext{
${ }^{60}$ Segundo LOURIVAL VILANOVA, um sistema "existe onde as partes são proposições e entre elas há relações que as agrupam num todo consistente, interiormente coerente". VILANOVA, Lourival. As estruturas lógicas e o sistema de direito positivo. São Paulo: Noeses, 2005, p. 163.
} 
Mesmo observado em partes distintas para fins didáticos - dentre as quais se destaca o conjunto de normas que regulam a atividade financeira do Estado -, o sistema mantém sua complexidade orgânica, unitária. Com efeito, a pesquisa não poderá deixar de abordar as relações entre os diferentes subsistemas normativos relacionados com o tema da transparência, na unidade estrutural do ordenamento jurídico.

Uma ressalva derradeira: intenta-se não apenas descrever a realidade como ela é, mas apontar como ela deveria ser. Afinal, o direito positivo e sua aplicação cotidiana não são realidades imutáveis, e as transformações que experimentam também possuem lastro no pensamento crítico produzido no universo acadêmico.

O caminho é desafiador. Apesar das dificuldades inerentes ao encarceramento de uma multiplicidade de pensamentos na linearidade do texto, a hora é de seguirmos a jornada, iniciada pela gênese do conceito de transparência. 


\section{CONCLUSÕES}

"Não existiria som

Se não houvesse o silêncio;

Não haveria luz

Se não fosse a escuridão.

A vida é mesmo assim,

Dia e noite, não e sim...

(...)

Nós somos medo e desejo,

Somos feitos de silêncio e sons.

Tem certas coisas que não sei dizer..."

(Lulu Santos / Nelson Motta)

"De tudo, ficaram três coisas: a certeza de que ele estava sempre começando, a certeza de que era preciso continuar e a certeza de que seria interrompido antes de terminar. Fazer da interrupção um caminho novo. Fazer da queda um passo de dança, do medo uma escada, do sono uma ponte, da procura um encontro".

(Fernando Sabino)

A tese que ora se completa nasceu de uma dúvida inquietante. De largada, não parecia claro - nem nos livros nem na vida - o conteúdo do princípio da transparência, diuturnamente reverberado na aplicação do direito financeiro brasileiro. Linha por linha, pouco a pouco, a dúvida originária foi dissipada, juntamente com outras adjacentes, que marcaram o caminho da investigação.

Por evidente, o leitmotiv que guiou a composição do trabalho, enredando cenários, personagens, valores e normas, não finda no pensamento que expusemos. O tema tratado abrange uma realidade em contínua transformação, renovando-se e iniciando trilhas inéditas no processo de 
construção e aplicação do direito financeiro. Contudo, algumas conclusões provisórias e sempre sujeitas a questionamentos - precisam ser compartilhadas em breve desfecho.

A transparência está associada à ideia de visibilidade das finanças públicas sem distorções, podendo ser compreendida como fato, como valor e como norma jurídica. Em sua dimensão normativa, afirma-se como um princípiogarantia inafastável, que direciona a atividade financeira do Estado Democrático de Direito brasileiro. Trata-se de princípio constitucional explícito (art. 216-A, $\S 1^{\circ}$, IX, da CF/88), fundamentado a partir de um amplo plexo de normas que compõem a moldura do direito financeiro.

Materialmente, o princípio da transparência objetiva promover um estado ideal de acessibilidade, inteligibilidade e confiabilidade das informações concernentes à atividade financeira pública em todos os entes federados, vinculando o Poder Executivo, o Poder Judiciário, o Poder Legislativo, os Tribunais de Contas, o Ministério Público, a Advocacia Pública e a Defensoria Pública.

Em que pesem os avanços densificadores do princípio da transparência, observados na última década, ainda é premente aprimorar a acessibilidade, a inteligibilidade e a confiabilidade dos fluxos de informações sobre a atividade financeira do Estado Democrático de Direito brasileiro. Há focos de opacidade, em diferentes graus, no planejamento governamental, na arrecadação de receitas públicas, na realização de despesas e no endividamento público. A vida financeira dos entes políticos "como ela é" tem destoado daquilo que deve ser.

Quanto maior o grau de opacidade, menor a visibilidade da atividade financeira estatal, e maiores os riscos de malversação de recursos públicos e conversão do espaço de todos (a "praça financeira") em "jardins secretos" de poucos. Essa opacidade demanda o enfrentamento de trincheiras em busca de caminhos normativos para garantir um maior controle sobre as finanças públicas.

Na luta preventiva e repressiva contra possíveis desvios no exercício do poder político-financeiro no regime democrático brasileiro, uma das principais 
armas disponibilizadas pelo direito financeiro é o princípio da transparência. Fazse crucial compreender a sua significação e operacionalidade a fim de manejá-lo da melhor forma possível, resguardando seu conteúdo essencial. Foi com esse intuito que procuramos examinar seus aspectos constitutivos, na tridimensionalidade fático-axiológica-normativa do Estado Democrático de Direito brasileiro.

Ao promover a acessibilidade, a inteligibilidade e a confiabilidade das informações sobre a atividade financeira desempenhada nos diferentes níveis de governo (federal, estadual, distrital e municipal), o princípio da transparência instrumentaliza a controlabilidade do exercício do poder político-financeiro, condição essencial para as liberdades democráticas. O reforço dessas liberdades - notadamente do acesso à informação - integra a rota de emancipação do homem rumo à plenitude de suas potencialidades.

Entre medos e desejos, silêncios e sons, segredos e revelações, sonhos e realizações, a transparência vem logrando cada vez mais força normativa. Sua efetividade significa também a afirmação da liberdade do homem na busca pelo conhecimento. Uma busca que também nos levou a chegar até aqui.

É necessário, porém, encerrarmos o trajeto que propusemos ao início, mesmo sem ter visto todas as minúcias da complexa paisagem que a transparência oferece à percepção. Outras poderiam ter sido retratadas, mas lutar com palavras é sempre difícil: "são muitas, eu pouco"1000.

Ao fim do combate, sobrevive um alento: a certeza de que esta interrupção carrega a esperança de caminhos novos, se as palavras aqui lançadas conseguirem propiciar maior clareza sobre a estrutura normativa e a importância do princípio da transparência no direito financeiro brasileiro.

${ }^{1000}$ ANDRADE, Carlos Drummond de. O lutador. Nova reunião: 23 livros de poesia - volume 1. Rio de Janeiro: Bestbolso, 2009, p. 121. 


\section{REFERÊNCIAS BIBLIOGRÁFICAS}

ABRAHAM, Marcus. Transparência e cidadania fiscal nos 15 anos da Lei de Responsabilidade Fiscal. Revista Fórum de Direito Financeiro e Econômico RFDFE, Belo Horizonte, ano 5, n. 8, set./fev. 2016.

ACCETTO, Torquato. Della dissimulazione onesta. A cura di Salvatore Silvano Nigro. Torino: Einaudi, 1997.

ACEMOGLU, Daron; ROBINSON, James A. Why naitons fail: the origins of power, prosperity and poverty. New York: Crown Business, 2012.

ACKERMAN, John M. (Coord.). Más allá del acceso a la información: transparencia, rendición de cuentas y Estado de derecho. México: Siglo XXI, 2008.

ADEODATO, João Maurício. A retórica constitucional: sobre tolerância, direitos humanos e outros fundamentos éticos do direito positivo. São Paulo: Saraiva, 2009.

AFONSO, José Roberto. As intricadas relações entre política fiscal e creditícia no Brasil Pós-2008. Revista Econômica, Niterói, v. 13, n. 2, dez. 2011.

Orçamento público no Brasil: história e premência de reforma. Espaço Jurídico Journal of Law, v. 17, n. 1, p. 9-28, jan./abr. 2016.

ALASDAIR, Roberts. Blacked out: government secrecy in the information age. Cambridge: Cambridge University Press, 2006.

ALBERGAMO, Maria (Ed.). La transparencia engaña. Madrid: Biblioteca Nueva, 2014.

ALESINA, Alberto e PEROTTI, Roberto. Fiscal discipline and the budget process. The American Economic Review, v. 86, n. 2, mai. 1996.

ALEXY, Robert. Teoria dos direitos fundamentais. Trad. Virgílio Afonso da Silva. São Paulo: Malheiros, 2008.

ALMINO, João. O segredo e a informação: ética e política no espaço público. São Paulo: Brasiliense, 1986.

ALT, James E. e LASSEN, David Dreyer. Fiscal transparency, political parties, and debt in OECD countries. European Economic Review, v. 50, n. 6, p. 14031439, 2006.

ALT, James; LASSEN, David Dreyer; ROSE, Shanna. The causes of fiscal transparency: evidence from the American States. IMF Staff Papers, v. 53, p. 3057, 2006. 
ALT, James; LESSEN, David Dreyer; WEHNER, Joachim. It isn't just about Greece: domestic politics, transparency and fiscal gimmickry in Europe. British Journal of Political Science, v. 44, n. 4, p. 707-716, out. 2014.

ALVES, Diego Prandino. Divergências entre instrumentos de controle social no Brasil: uma comparação entre dados do Portal da Transparência, dos relatórios de gestão anuais de entidades públicas e do Relatório do Tribunal de Contas da União sobre as Contas da República. Fórum de Contratação e Gestão Pública FCGP, Belo Horizonte, ano 10, n. 114, p. 64-79, jun. 2011.

ALVES, Marcus Vinícius Chevitarese. Transparência orçamentária efetiva e Internet: um estudo a partir dos portais eletrônicos de orçamento da Câmara dos Deputados e do Senado Federal. Disponível em: <http://bd.camara.gov.br/bd/handle/bdcamara/5644>. Acesso em: 19 jul.

AMARAL JÚNIOR, José Levi Mello do. O Poder Legislativo na democracia contemporânea: a função de controle político dos parlamentos na democracia contemporânea. Revista de Informação Legislativa, Brasília, v. 168, p. 7-17, 2005.

Questões jurídicas relativas aos conselhos profissionais e à liberdade de profissão no Brasil. Revista Direitos Humanos Fundamentais, Osasco, v. 8, n. 2.

ARAÚJO, Inaldo da Paixão Santos; FEIJÓ, Paulo Henrique; GAMA, Janyluce Rezende. Transparência no setor público: uma proposta para incentivar. Revista Técnica dos Tribunais de Contas - RTTC, Belo Horizonte, ano 2, n. 1, set. 2011.

ARBATLI, Elif; ESCOLANO, Julio. Fiscal transparency, fiscal performance and credit ratings. Fiscal Studies, v. 36, p. 237-270, 2015.

ARENDT, Hannah. The human condition. Introduction by Margaret Canovan. 2. ed. Chicago: University of Chicago Press, 1998.

ARISTÓTELES. Sobre a alma. Trad. Ana Maria Lóio. Lisboa: Imprensa Nacional, 2010.

ASSONI FILHO, Sérgio. Transparência fiscal e democracia. Porto Alegre: Núria Fabris, 2009.

ATALIBA, Geraldo. Empréstimos públicos e seu regime jurídico. São Paulo: Revista dos Tribunais, 1973.

República e Constituição. 2. ed. São Paulo: Malheiros, 2007.

ATIENZA, Manuel. El derecho como argumentación. Barcelona: Ariel, 2006.

ÁVILA, Humberto. A distinção entre princípios e regras e a redefinição do dever de proporcionalidade. Revista de Direito Administrativo, Rio de Janeiro, v. 215, jan./mar. 1999. 
Moralidade, razoabilidade e eficiência na atividade administrativa. Revista Brasileira de Direito Público - RBDP, Belo Horizonte, n. 1, ano 1, abr./jun. 2003.

. Teoria dos princípios: da definição à aplicação dos princípios jurídicos. 9 . ed. São Paulo: Malheiros, 2009.

. Segurança jurídica: entre permanência, mudança e realização no direito tributário. São Paulo: Malheiros, 2011.

AVRITZER, Leonardo et. al. (Org.). Corrupção: ensaios e críticas. 2. ed. Belo Horizonte: UFMG, 2012.

AVRITZER, Leonardo e FILGUEIRAS, Fernando. Corrupção e controles democráticos no Brasil. Textos para discussão CEPAL-IPEA, 32. Brasília: CEPAL/IPEA, 2011.

BADIN, Luiz Armando. O direito fundamental à informação em face da segurança do Estado e da sociedade: em busca da efetiva afirmação do princípio constitucional da publicidade. Tese (Doutorado em Direito). Faculdade de Direito da Universidade de São Paulo, 2007.

BALEEIRO, Aliomar. Uma introdução à ciência das finanças. 17. ed., atualizada por Hugo de Brito Machado Segundo. Rio de Janeiro: Forense, 2010.

O direito financeiro na Constituição de 1967. Revista de Informação Legislativa, v. 6, n. 21, p. 3-30, jan./mar. 1969.

BARBOSA, Rui. Obras completas. Rio de Janeiro: Ministério da Educação e Saúde, 1947, v. XVI, Tomo I.

BARILE, Paolo. Democrazia e segreto. Quaderni Costituzionali, n. 1, p. 29-50, 1987.

BARRETO, Tobias. Estudos de direito. Rio de Janeiro: Laemmert \& C., 1892.

BARROS, Antonio Teixeira de. O projeto de transparência do Senado Federal: entre a accountability e a propaganda política. Sociologias, Porto Alegre, ano 17, n. 39, p. 338-368, mai/ago 2015.

BARROSO, Luís Roberto. O direito constitucional e a efetividade de suas normas: limites e possibilidades da Constituição brasileira. 8 ed. Rio de Janeiro: Renovar, 2006.

BASTOS, Celso Ribeiro. O princípio da moralidade no direito público. Revista de Direito Constitucional e Internacional, v. 22, p. 44-54, jan./mar. 1998.

BASTOS, Frederico Silva e CHRISTOPOULOS, Basile Georges Campos. Administração tributária eficiente, democracia e desenvolvimento: experiências internacionais sobre índices de transparência fiscal e sua utilidade para o Brasil. Revista Discente Direito GV, São Paulo, ano 1, v.1, n.2, ago. 2012. 
BAUME, Sandrine. Transparency in the handling of public affairs. Origins and meaning of a requirement. Disponivel a partir de: <https://spaa.newark.rutgers.edu/>. Acesso em: 14 fev. 2016.

BEHN, Robert D. O novo paradigma da gestão pública e a busca da accountability democrática. Revista do Serviço Público, Brasília, ano 49, n. 4, out./dez. 1998.

BELORGEY, Jean-Michel. L'Etat entre transparence et secret. Pouvoirs - Revue française d'études constitutionnelles et politiques, n. 97, avril 2001.

BERCOVICI, Gilberto. Dilemas da concretização da constituição de 1988. Revista do Instituto de Hermenêutica Jurídica - RIHJ, Belo Horizonte, ano 1, n. 2, jan. / dez. 2004.

- Constituição Econômica e desenvolvimento: uma leitura a partir da Constituição de 1988. São Paulo: Malheiros, 2005.

. Direito econômico do petróleo e dos recursos minerais. São Paulo: Quartier Latin, 2011.

. Poder Constituinte do povo no Brasil: um roteiro de pesquisa sobre a crise constituinte. Lua Nova, São Paulo, n. 88, p. 305-325, 2013.

BERNOTH, Kerstin; WOLFF, Guntram B. Fool the markets? Creative accounting, fiscal transparency and sovereign risk premia. Scottish Journal of Political Economy, v. 55, n. 4, p. 465-487, 2008.

BERSCH, Katherine e MICHENER, Greg. Conceptualizing the quality of transparency. Paper prepared for the $1^{\text {st }}$ Global Conference on Transparency. Disponível a partir de: <http://www.gregmichener.com>. Acesso em: 25 ago. 2016.

BEST, Jacqueline. The limits of transparency: ambiguity and the history of international finance. Ithaca: Cornell University Press, 2005.

BIANCHI, Andrea; PETERS, Anne (Ed.). Transparency in international law. New York: Cambridge University Press, 2013.

BIANCO, João Francisco. Transparência fiscal internacional. São Paulo: Dialética, 2007.

BIDERMAN, Ciro e ARVATE, Paulo (Org.). Economia do setor público no Brasil. Rio de Janeiro: Elsevier, 2004.

BIM, Eduardo Fortunato. Audiências públicas. São Paulo: Revista dos Tribunais, 2014.

BINENBOJM, Gustavo. A advocacia pública e o Estado Democrático de Direito. Revista Brasileira de Direito Público - RBDP, Belo Horizonte, ano 8, n. 31, out./dez. 2010. 
BIRCHALL, Clare. Introduction to 'secrecy and transparency': the politics of opacity and opennness. Theory, Culture \& Society, v. 28, n. 7-8, december 2011.

BIRD, Richard. Visibility and accountability. Is tax-inclusive pricing a good thing? Canadian Tax Journal, v. 58, n. 1, p. 63-76, 2010.

BLINDER, Alan S. The quiet revolution: central banking goes modern. New Haven: Yale University Press, 2004.

BOBBIO, Norberto. A era dos direitos. Trad. Carlos Nelson Coutinho. Rio de Janeiro: Campus, 1992.

. Il futuro della democrazia. Torino: Einaudi, 1995.

. Democrazia e segreto. Torino: Einaudi, 2011.

BÖCKENFÖRDE, Ersnt Wolfgang. Estudios sobre el Estado de Derecho y la democracia. Trad. Rafael de Agapito Serrano. Madrid: Trota, 2000.

BONAVIDES, Paulo. Curso de direito constitucional. 15. ed. São Paulo: Malheiros, 2004.

.Teoria constitucional da democracia participativa. 3. ed. São Paulo: Malheiros, 2008.

BONOMO, Annamaria. Informazione e pubbliche amministrazioni: dall'accesso ai documenti alla disponibilità delle informazioni. Bari: Cacucci, 2012.

BORGES, José Souto Maior. Introdução ao direito financeiro. São Paulo: Max Limonad, 1998.

. Ciência feliz. 3. ed. São Paulo: Quartier Latin, 2007.

. Um ensaio interdisciplinar em direito tributário: superação da dogmática. Revista Dialética de Direito Tributário, n. 211, São Paulo, abr/2013.

BOURDIEU, Pierre. Sur l'État. Paris: Raisons d'agir, 2012.

BOUVIER, Michel. La nouvelle gouvernance financière publique au coeur de la reforme de l'état démocratique. Vigie, Québec, v. 10, n. 3, décembre 2007.

BOUVIER, Michel (Dir.). La transparence des finances publiques: vers un nouveau modele. Paris: LGDJ, 2013.

BOUVIER, Michel; ESCLASSAN, Marie-Christine; LASSALE, Jean-Pierre. Finances publiques. 11. ed. Paris: L.G.D.J, 2012. 
BOWLES, Nigel; HAMILTON, James T.; LEVY, David A. L. (Ed.). Transparency in politics and the media: accountability and open government. New York: Tauris \& Co., 2014.

BOWRING, John. The works of Jeremy Bentham. Edinburgh: William Tait, 1843, V. 1.

. The works of Jeremy Bentham. Edinburgh: William Tait, 1843, v. 4.

BRÄUTIGAM, Deborah. The people's budget? Politics, participation and pro-poor policy, Development Policy Review, vol. 22, n. 6, nov. 2004, p. 653-668.

BREDIN, Jean-Denis. Secret, transparence et démocratie. Pouvoirs - Revue française d'études constitutionnelles et politiques, n. 97, avril 2001.

BRITTO, Carlos Ayres. Distinção entre "controle social do poder" e "participação popular". Revista de Direito Administrativo, Rio de Janeiro, v. 189, jul./set. 1992.

2012.

O humanismo como categoria constitucional. Belo Horizonte: Fórum,

BUCHANAN, James M. Public finance in democratic process: fiscal institutions and individual choice. Indianapolis: Liberty Fund, 1999.

BUENO, José Antonio Pimenta. Direito publico brazileiro e analyse da Constituição do Imperio. Rio de Janeiro: Typographia Imp. e Const. de J. Villeneuve \& C., 1857.

BUIZJE, Anoeska. The six faces of transparency. Utrecht Law Review, v. 9, n. 3, jul. 2013.

CABRAL, Nazaré da Costa. Programação e decisão orçamental: da racionalidade das decisões orçamentais à racionalidade económica. Coimbra: Almedina, 2008.

CAMPOS, Haroldo de. Deus e o diabo no Fausto de Goethe. São Paulo: Perspectiva, 1981.

CAMUS, Albert. Discours de suéde. Paris: Gallimard, 1958.

CANARIS, Claus-Wilhelm. Pensamento sistemático e conceito de sistema na ciência do direito. 5. ed. Lisboa: Fundação Calouste Gulbenkian, 2012.

CANETTI, Elias. Crowds and power. Translated from the German by Carol Stewart. New York: Continuum, 1978.

CARLITZ, Ruth. Improving transparency and accountability in the budget process: an assessment of recent initiatives. Development Policy Review, v.31, p.49-67, jul. 2013.

CARRAZZA, Roque Antonio. Curso de Direito Constitucional Tributário. 21 ed. São Paulo: Malheiros, 2005. 
CARREIRA, Liberato de Castro. Historia financeira e orçamentaria do Imperio do Brazil desde a sua fundação, precedida de alguns apontamentos acerca da sua Independencia. Rio de Janeiro: Imprensa Nacional, 1889.

CARRIÓ, Genaro R. Notas sobre derecho y lenguaje. 3. ed. Buenos Aires: Abeledo-Perrot,1986.

CARVALHO, Paulo de Barros. Direito tributário, linguagem e método. 2. ed. São Paulo: Noeses, 2008

A interpretação em matéria tributária. Interesse Público - IP, Belo Horizonte, ano 17, n. 92, p. 101-116, jul./ago. 2015.

CARVALHO FILHO, José dos Santos. Manual de direito administrativo. 30 ed. São Paulo: Atlas, 2016.

CASSIRER, Ernst. An essay on man: an introduction to a philosophy of human culture. New Haven: Yale University Press, 1944.

CASTELLS, Manuel. A era da informação: economia, sociedade e cultura, v. 1: a sociedade em rede. 9. ed. Trad. Roneide Venâncio Majer. São Paulo: Paz e Terra, 2006.

. O poder da comunicação. Trad. Vera Lúcia Mello Joscelyne. São Paulo: Paz e Terra, 2015.

CASU, Antonio. Democrazia e sicurezza. L'istituzione parlamentare e le sfide del nuovo scenario internazionale. Soveria Mannelli: Rubbettino, 2005.

CATARINO, João Ricardo. Finanças públicas e direito financeiro. Coimbra: Almedina, 2012.

CAVALCANTE, Denise Lucena; CABRAL, Denise Maciel de Albuquerque. Os custos das políticas públicas: um olhar para o orçamento com foco no gasto. Revista de Direito Internacional Econômico e Tributário, Brasília, v. 9, n. 1, p. 118, jan./jun., 2014.

CAVALCANTE, Denise Lucena; CAMURÇA, Eulália. Cidadania fiscal: o direito à informação da carga tributária no Brasil. Revista Tributária e de Finanças Públicas, v. 104, p. 35-52, mai./jun. 2012.

CERRILLO, Agustí. Los principios de los datos abiertos en la legislación española. Revista de los Estudios de Derecho y Ciencia Política, n. 19, Octubre, 2014, p. 6277.

CHAPMAN, Richard A.; HUNT, Michael (Ed.). Freedom of information: local government and accountability. New York: Routledge, 2016.

CHAUÍ, Marilena. Convite à filosofia. São Paulo: Ática, 2000.

CHEVALLIER, Jacques. L'État post-moderne. 3. ed. Paris: LGDJ, 2008. 
CLÈVE, Clémerson Merlin. O cidadão, a administração pública e a nova Constituição. Revista de Informação Legislativa, Brasília, n. 106, abr./jun. 1990.

CLIMENT, Miguel Ángel Blanes. La transparencia informativa de las Administraciones públicas: el derecho de las personas a saber y la obligación de difundir información pública de forma activa. Cizur Menor: Aranzadi, 2014.

COMPARATO, Fábio Konder. A nova cidadania. Lua Nova, São Paulo, n. 2829, p. 85-106, abr. 1993.

CONTI, José Maurício. A autonomia financeira do Poder Judiciário. São Paulo: MP, 2006.

. Levando o direito financeiro a sério. São Paulo: Blucher, 2016.

CONTI, José Maurício (Coord.). Orçamentos públicos: a Lei 4.320/1964 comentada. São Paulo: Revista dos Tribunais, 2008.

CONTI, José Maurício e SCAFF, Fernando Facury (Coord.). Orçamentos públicos e direito financeiro. São Paulo: Revista dos Tribunais, 2011.

CORREIA NETO, Celso de Barros. O avesso do tributo. 2. ed. São Paulo: Almedina, 2016.

CORTI, Horacio Guillermo. Derecho financiero. Buenos Aires: Abeledo-Perrot, 1997.

Argentina, 2007.

. Derecho constitucional presupuestario. Buenos Aires: Lexis Nexis . Ley de presupuesto y derechos fundamentales: los fundamentos de un nuevo paradigma jurídico-financiero. Revista Jurídica de Buenos Aires, Universidad de Buenos Aires, 2010, Tomo I, p. 637-690.

COSTA, Pietro; ZOLO, Danilo; SANTORO, Emilio (Org.). O Estado de Direito: história, teoria, crítica. Trad. Carlo Alberto Dastoli. São Paulo: Martins Fontes, 2006.

COTINO HUESO, Lorenzo. Teoría y realidad de la transparencia pública en Europa. Valencia: Tirant lo Blanch, 2003.

.Transparencia y derecho de acceso a los documentos en la Constitución Europea y en la realidad de su ejercicio. Valencia: Tirant lo Blanch, 2006.

- La nueva ley de transparencia y acceso a la información. Anuario

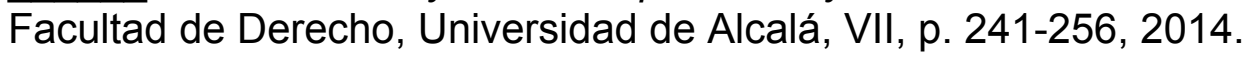

COUTINHO, Diogo Rosenthal. Direito, desigualdade e desenvolvimento. São Paulo: Saraiva, 2013. 
COUTO E SILVA, Almiro do. O princípio da segurança jurídica (proteção à confiança) no direito público brasileiro e o direito da Administração Pública de anular seus próprios atos administrativos: o prazo decadencial do art. 54 da lei do processo administrativo da União (Lei $n^{\circ}$ 9.784/99). Revista Eletrônica de Direito do Estado, Salvador, Instituto de Direito Público da Bahia, n. 2, abril/maior/junho, 2005.

CRUZ, Flávio da (coord.). Lei de responsabilidade fiscal comentada. São Paulo: Atlas, 2001.

CUKIERMAN, Alex. Are contemporary Central Banks transparent about economic models and objectives and what difference does it make? Review, Federal Reserve Bank of St. Louis, v. 84, n. 4, p. 15-35, 2002.

CUNHA, Armando; REZENDE, Fernando. O orçamento dos brasileiros: por que ele não desperta maior interesse? Rio de Janeiro: FGV Projetos, 2014.

DALLARI, Dalmo de Abreu. Os direitos fundamentais na Constituição brasileira. Revista da Faculdade de Direito da Universidade de São Paulo, v. 88, p. 421-437, 1993.

DANIEL, Jean-Marc. Histoire vivante de la pensée économique: des crises et des hommes. Paris: Pearson, 2010.

D'AURIA, Francisco. Ciência das finanças (teoria e prática). São Paulo: Companhia Editora Nacional, 1947.

DAVID-BARRETT, Elizabeth; OKAMURA, Ken. Norm diffusion and reputation: the rise of the Extractive Industries Transparency Initiative. Governance: an International Journal of Policy, Administration, and Institutions, v. 29, n. 2, p. $227-$ 246, April 2016.

DE LUCAS MARTÍN, Francisco Javier. Anotaciones sobre el principio kantiano de publicidad. Diánoia, v. 33, n. 33, p. 131-148, 1987.

.Democracia y transparencia: sobre poder, secreto y publicidad. Anuario de filosofía del derecho, n. 7, p. 131-146,1990.

DELGADO, José Augusto. O princípio da moralidade administrativa e a Constituição Federal de 1988. Revista dos Tribunais, v. 680, p. 34-46, jun. 1992.

DEODATO, Alberto. Manual de ciência das finanças. 12. ed. São Paulo: Saraiva, 1971.

DI PIETRO, Maria Sylvia Zanella. Participação popular na administração pública. Revista de Direito Administrativo, Rio de Janeiro, v. 191, jan./mar. 1993.

DIAMOND, Larry. The spirit of democracy: the struggle to build free societies throughout the world. New York: Holt Paperbacks, 2009. 
DIAS, Jorge de Figueiredo; BARRETO, Ireneu Cabral; BELEZA, Teresa Pizarro; FERREIRA, Eduardo Paz. Estudos em homenagem a Cunha Rodrigues. Coimbra: Coimbra Editores, 2001, v. 2.

DÍAZ, Elías. Estado de Derecho y sociedad democrática. Madrid: Taurus, 2010.

. Estado de derecho y democracia. Anuario de la Faculdad de Derecho, n. 19, p. 201-217, Universidad de Extremadura, 2001.

DRIESSEN, Bart. Transparency in EU institutional law: a practitioner's handbook. London: Cameron May, 2008.

DURAN, Camila Villard. A moldura jurídica da política monetária: um estudo do BACEN do BCE e do FED. São Paulo: Saraiva, 2013.

DWORKIN, Ronald. Taking rights seriously. Cambridge: Harvard University Press, 1978.

. Freedom's law: the moral reading of the American Constitutuion. Cambridge: Harvard University Press, 1996.

ECO, Umberto. Tratado de semiótica general. Trad. de Carlos Manzano. Barcelona: Lumen, 2000.

ELIAS, Gustavo Terra. Da publicidade à transparência: o percurso para a reafirmação da democracia participativa. Fórum Administrativo - FA, Belo Horizonte, ano 12, n. 141, p. 27-40, nov. 2012.

ELIAS, Nobert. O processo civilizador. Trad. Ruy Jungmann. Rio de Janeiro: Zahar, 1993, v. 2.

FAORO, Raymundo. Os donos do poder: formação do patronato político brasileiro. 3. ed. Rio de Janeiro: Globo, 2001.

FASIANI, Mauro. Principios de ciencia de la hacienda. Versión española de Gabriel de Usera. Madrid: Aguilar, 1962.

FEIJÓ, Paulo Henrique; PINTO, Liane Ferreira; MOTA, Francisco Glauber Lima. Curso de Siafi: uma abordagem prática da execução orçamentária e financeira. 2. ed. Brasília: Gestão Pública, 2009.

FENSTER, Mark. The opacity of transparency. Iwoa Law Review, v. 91, p. 885949, 2006. v. $62,2010$.

. Seing the State: transparency as a metaphor. Administrative Law Review, Transparency in search of a theory. European Journal of Social Theory, v. 18, n. 2, 2015. 
FERNANDES, Andressa Guimarães Torquato. Royalties do petróleo e orçamento público: uma nova teoria. São Paulo: Blucher, 2016.

FERRAJOLI, Luigi. Constitucionalismo principialista y constitucionalismo garantista. Doxa, Cuadernos de Filosofía del Derecho, n. 34, 2011.

FERRAZ, Luciano. Além da sociedade de economia mista. Revista de Direito Administrativo, Belo Horizonte, v. 266, mai./ago. 2014.

FERRAZ JUNIOR, Tercio Sampaio. Sigilo de dados: o direito à privacidade e os limites à função fiscalizadora do Estado. Revista da Faculdade de Direito da Universidade de São Paulo, v. 88, p. 439-459, 1993.

. Introdução ao estudo do direito: técnica, decisão, dominação. 3. ed. São Paulo: Atlas, 2001.

- Teoria da norma jurídica: ensaio de pragmática da comunicação normativa. 4. ed. Rio de Janeiro: Forense, 2006.

. Direito constitucional: liberdade de fumar, privacidade, estado, direitos humanos e outros temas. Barueri: Manole, 2007.

FERRY, Luc. A sabedoria dos mitos gregos. Trad. Jorge Bastos. Rio de Janeiro: Objetiva, 2012.

FERNÁNDEZ SALMERÓN, Manuel; VALERO TORRIJOS, Julián (Coord.). Régimen jurídico de la transparencia en el sector público: acceso, uso y reutilización de la información administrativa. Madrid: Thomson-Aranzadi, 2014.

FILGUEIRAS, Fernando. Além da transparência: accountability e política da publicidade. Lua Nova, São Paulo, n. 84, p. 353-364, 2011.

FIORI, Elcio Henriques. Os benefícios fiscais no direito financeiro e orçamentário: o gasto tributário no direito brasileiro. São Paulo: Quartier Latin, 2010.

FLORINI, Ann (Ed.). The right to know: transparency for an open world. New York: Columbia University Press, 2007.

FLUSSER, Vilém. Língua e realidade. 3. ed. São Paulo: Annablume, 2007.

O mundo codificado: por uma filosofia do design e da comunicação. Organizado por Rafael Cardoso. Trad. Raquel Abi-Sâmara. São Paulo: Cosac Naify, 2007.

FÖLSCHER, Alta. Budget transparency: new frontiers in transparency and accountability. London: Open Society Foundation, 2010.

FORSSBÆECK, Jens; OXELHEIM, Lars (Ed.). The Oxford handbook of economic and institutional transparency. New York: Oxford University Press, 2015. 
FOUCAULT, Michel. Segurança, território, população: curso dado no Collège de France (1977-1978). Trad. Eduardo Brandão. São Paulo: Martins Fontes, 2008.

O governo de si e dos outros: curso no Collège de France (1982-1983). Trad. Eduardo Brandão. São Paulo: WMF Martins Fontes, 2010.

- Microfísica do poder. Organização, introdução e revisão técnica de Roberto Machado. 2. ed. São Paulo: Paz e Terra, 2015.

FOUNTAIN, Jane E. Building the virtual state: information, technology and institutional change. Washington, D.C.: Bookings Institution Press, 2001.

FRANCO, António L. de Sousa. Finanças públicas e direito financeiro. 4. ed. Coimbra: Almedina, 2010.

FREITAS, Juarez. O princípio constitucional da moralidade e o novo controle das relações de administração. Interesse Público - IP, Belo Horizonte, n. 51, ano 10, set./out. 2008.

. O regime constitucional dos bens das sociedades de economia mista e das empresas públicas. Interesse Público - IP, Belo Horizonte, ano 12, n. 64, nov./dez. 2010. Malheiros, 2014.

FUNG, Archon; KHAGRAM, Sanjeev; RENZIO, Paolo de (Ed.). Open budgets: the political economy of transparency, participation and accountability. Washington: Brookings Institution Press, 2013.

FUNG, Archon; GRAHAM, Mary; WEIL, David. Full disclosure: the perils and promise of transparency. New York: Cambridge University Press, 2013.

FUKADA-PARR, Sakiko; GUYER, Patrick; LAWSON-REMER, Terra. Does budget transparency lead to stronger human development outcomes and commitments to economic and social rights? International Budget Partnerships Working Paper, $\mathrm{n}$. 4, December 2011. Disponível em: <http://ssrn.com/abstract=2211584>. Acesso em: 24 jun. 2015.

GARCÍA DE ENTERRÍA, Eduardo; CLAVERO ARÉVALO, Manuel Francisco; ARAGON REYES, Manuel (Dir.). El derecho publico de finales de siglo: una perspectiva iberoamericana. Madrid: Civitas, 1997.

GARCÍA DE ENTERRÍA, Eduardo; FERNÁNDEZ, Tomás-Ramón. Curso de direito administrativo. Trad. José Alberto Froes Cal. São Paulo: Revista dos Tribunais, 2014, v. 2.

GAUDEMET, Paul-Marie; MOLINIER, J. Finances publiques. Budget et Trésor. 7. ed. Paris: Montchrestien, 1996. 
GERAATS, Petra M. Central Bank transparency. The Economic Journal, v. 112, p. 532-565, nov. 2002.

GIACOMONI, James. Orçamento público. 15. ed. São Paulo: Atlas, 2010.

GIAMBIAGI, Fabio. 18 anos de política fiscal no Brasil: 1991/2008. Economia Aplicada, São Paulo, v. 12, n. 4, p. 535-580, out./dez. 2008.

GLENNERSTER, Rachel; SHIN, Yongseok. Does transparency pay? IMF Staff Papers, v. 55, n. 1, p. 183-209, 2008.

GLOTZ, G. The greek city and its institutions. Translated by N. Mallinson. London: Routledge, 1996.

GOLDSCHMIDT, Maure L. Publicity, Privacy and Secrecy. The Western Political Quarterly, v. 7, n. 3, p. 401-416, sep. 1954.

GOMES, Emerson Cesar da Silva. O direito dos gastos públicos no Brasil. São Paulo: Almedina, 2015.

GOMES, Marcus Lívio; ABRAHAM, Marcus; TORRES, Heleno Taveira (Coord.). Direito financeiro na jurisprudência do Supremo Tribunal Federal: homenagem ao Ministro Marco Aurélio. Curitiba: Juruá, 2016.

GONZÁLEZ GARCÍA, Eusebio. Introducción al derecho presupuestario: concepto, evolución histórica y naturaleza jurídica. Madrid: Editorial de Derecho Financiero, 1973.

GORDILLO, Agustín. Tratado de derecho administrativo y obras selectas: el derecho administrativo en la práctica. Buenos Aires: Fundación de Derecho Administrativo, 2013, tomo 7.

GRAÇA, Luís Otávio Barroso da. Transparência no processo orçamentário. Revista de Informação Legislativa, v. 40, n. 160, p. 353-360, out./dez. 2003.

GRAU, Eros Roberto. Planejamento econômico e regra jurídica. São Paulo: Revista dos Tribunais, 1978.

. Equidade, razoabilidade, proporcionalidade e princípio da moralidade. Revista do Instituto de Hermenêutica Jurídica, Belo Horizonte, ano 1, n. 3, jan./dez. 2005.

. Ensaio e discurso sobre a interpretação/aplicação do direito. 4. ed. São Paulo: Malheiros, 2006.

2008.

O direito posto e o direito pressuposto. 7. ed. São Paulo: Malheiros,

Por que tenho medo dos juízes (a interpretação/aplicação do direito e os princípios). São Paulo: Malheiros, 2013. 
GRECO, Marco Aurelio. Notas sobre o princípio da moralidade: uma abordagem apoiada no elemento alteridade. Revista Brasileira de Direito Público - RBDP, Belo Horizonte, ano 12, n. 45, abr./jun. 2014.

GRECO, Marco Aurélio; MARTINS, Ives Gandra da Silva (Coord.). Direito e Internet: relações jurídicas na sociedade informatizada. São Paulo: Revista dos Tribunais, 2001.

GRINOVER, Ada Pellegrini et. al. Problemas e reformas: subsídios para o debate constituinte. São Paulo: Ordem dos Advogados do Brasil, 1988.

GUICHOT, Emilio. Transparencia y acceso a la información en el derecho europeo. Sevilla: Derecho Global, 2011.

GUICHOT, Emilio (Coord.). Transparencia, acceso a la información pública y buen gobierno: estudio de la ley 19/2013, de 9 de diciembre. Madrid: Tecnos, 2014.

GUITTON, Jean. Le clair et l'obscur. Paris: Éditions Aubier, 1964.

HABER NETO, Michel. Transparência fiscal e sigilo tributário. Tese (Doutorado em Direito). Faculdade de Direito da Universidade de São Paulo, 2015.

HÄBERLE, Peter. Os problemas da verdade no Estado constitucional. Trad. Urbano Carvelli. Porto Alegre: Sergio Antonio Fabris, 2008.

HABERMAS, Jüngen. Direito e democracia: entre facticidade e validade. 2. Ed. Trad. Flávio Beno Siebeneichler. Rio de Janeiro: Tempo Brasileiro, 2012, v. 1.

. Mudança estrutural na esfera pública: investigações sobre uma categoria da sociedade burguesa. Trad. Denilson Luís Werle. São Paulo: Unesp, 2014.

HAUGLE, Virginia. Disclosure as governance: the Extractive Industries Transparency Initiative and resource management in the developing world. Global Environmental Politics, v. 10, n. 3, p. 53-73, august 2010.

HAURIOU, Maurice. Principios de derecho público y constitucional. Trad. Carlos Ruiz del Castillo. Madrid: Reus, 1927.

HEALD, David. Fiscal transparency: concepts, measurement and UK practice. Public Administration, v. 81, n. 4, p. 723-759, dez. 2003.

Why is transparency about public expenditure so elusive? International Review of Administrative Sciences, v. 78, p. 30-49, mar. 2012.

HENDRIKSEN, Eldon S.; VAN BREDA, Michael F. Teoria da contabilidade. 5. ed. Trad. Antonio Zoratto Sanvincente São Paulo: Atlas, 1999.

HESÍODO. Teogonia: a origem dos deuses. Estudo e tradução de Jaa Torrano. 3. ed. São Paulo: Iluminuras, 1995. 
HESSE, Konrad. A força normativa da Constituição. Trad. Gilmar Ferreira Mendes. Porto Alegre: Fabris, 1991.

HESSE, Konrad. Temas fundamentais do direito constitucional. Textos selecionados e traduzidos por Carlos dos Santos Almeida, Gilmar Ferreira Mendes e Inocêncio Mártires Coelho. São Paulo: Saraiva, 2009.

HOLMES, Stephen e SUNSTEIN, Cass R. The cost of rights: why liberty depends on taxes. New York: W.W. Norton, 2000.

HOLZNER, Burkart; HOLZNER, Leslie. Transparency in global change: the vanguard of the open society. Pittsburgh: University of Pittsburgh Press, 2006.

HOMERCHER, Evandro T.; BERGUE, Sandro Trescastro. Políticas públicas e transparência: reflexões multidisciplinares. Interesse Público - IP, São Paulo, ano 13, n. 68, p. 405-422, jul./ago. 2011.

HOOD, Christopher. What happens when transparency meets blame-avoidance? Public Management Review, v. 9, n. 2, 2007.

HOOD, Christopher; HEALD, David (Ed.). Transparency: the key to better governance? New York: Oxford University Press, 2006.

HORVATH, Estevão. O direito tributário no contexto da atividade financeira do Estado. Tese (concurso de Professor Titular). Faculdade de Direito da Universidade de São Paulo, São Paulo, 2009.

O orçamento no século XXI: tendências e expectativas. Tese (concurso de Professor Titular). Faculdade de Direito da Universidade de São Paulo, São Paulo, 2014.

HORVATH, Estevão; CONTI, José Maurício; SCAFF, Fernando Facury (Org.). Direito financeiro, econômico e tributário: estudos em homenagem a Regis Fernandes de Oliveira. São Paulo: Quartier Latin, 2014.

ILLUMINATI, Giulio (Ed.). Nuovi profili del segreto di stato e dell'attività di intelligence. Torino: G. Giappichelli, 2010.

INTERNATIONAL MONETARY FUND. Current developments in monetary and financial law. Washington: IMF, 2003, v. 2.

Guide on resource revenue transparency. Washington: International Monetary Fund, 2007.

. Manual on fiscal transparency. Rev. ed. Washington: International Monetary Fund, 2007.

IRWIN, Timothy C. Accounting devices and fiscal illusions. IMF Staff Discussion Note, International Monetary Fund, 2012. 
. Shinning a light on the mysteries of State: the origins of fiscal transparency in Western Europe. IMF Working Paper 13/219, International Monetary Fund, 2013.

JARACH, Dino. Finanzas públicas y derecho tributario. Buenos Aires: Editorial Cangallo, 1993.

KANT, Immanuel. À paz perpétua. Trad. Marco Zingano. Porto Alegre: L\&PM, 2011.

KANTOROWICZ, Ernst $\mathrm{H}$. Mysteries of State: an absolutist concept and its late mediaeval origins. The Harvard Theological Review, v. 48, n. 1, , p. 65-91, jan. 1955.

KARL, Kerényi. A mitologia dos gregos: a história dos deuses e dos homens. Trad. Octavio Mendes Cajado. Petrópolis: Vozes, 2015.

KELSEN, Hans. Teoria pura do direito. Trad. João Baptista Machado. São Paulo: Martins Fontes, 2003.

KOEN, Vincent; NOORD, Paul van den. Fiscal gimmickry in Europe: one-off measures and creative accounting. OECD Economics Department Working Papers, n. 417, 2005.

KOIVISTO, Ida. The IMF and the "transparency turn". Minnesota Journal of International Law, v. 25, p. 381-420, 2006.

KOPITS, George; KRAIG, Jon. Transparency in government operations. Occasional paper n. 158. Washington: International Monetary Fund,1998.

KUHN, Thomas. The structure of scientific revolutions. Second edition, enlarged. Chicago: The University of Chicago Press, 1970.

LAFER, Celso. A reconstrução dos direitos humanos: um diálogo com o pensamento de Hannah Arendt. São Paulo: Companhia das Letras, 1988.

LEFEBVREA, Stéphane. A brief genealogy of state secrecy. Windsor Yearbook of Access to Justice, vol. 31, n. 1, p. 95-114, 2013.

LEVIN, David Michael (Ed.). Modernity and the hegemony of vision. Berkeley: University of California Press, 1993.

LÉVY, Pierre. O que é o virtual? Trad. Paulo Neves. São Paulo: 34, 1996.

LEWANDOWSKI, Enrique Ricardo. Reflexões em torno do princípio republicano. Revista da Faculdade de Direito da Universidade de São Paulo, v. 100, p. 189200, jan./dez. 2005.

LOCHAGIN, Gabriel Loretto. Elementos jurídicos da reestruturação internacional da dívida pública. Tese (Doutorado em Direito). Faculdade de Direito da Universidade de São Paulo, 2016. 
. A execução do orçamento público: flexibilidade e orçamento impositivo. São Paulo: Blucher, 2016.

LOPES, Cristiano Aguiar. Acesso à informação pública para a melhoria da qualidade dos gastos públicos - literatura, evidências empíricas e o caso brasileiro. Cadernos de Finanças Públicas, Brasília, n. 8, p. 5-40, dez. 2007.

LUCCA, Newton De; MEYER-PFLUG, Samantha Ribeiro; NEVES, Marina Barboza Baeta (Coord.). Direito constitucional contemporâneo. Homenagem ao Professor Michel Temer. São Paulo: Quartier Latin, 2012.

MACCORMICK, Neil. Argumentação jurídica e teoria do direito. Trad. Waldéa Barcellos. São Paulo: Martins Fontes, 2006.

MARTÍNEZ, Fernando Rey. Quod omnes tangit ab omnibus cognitum esse debet: el derecho de acceso a la información pública como derecho fundamental. Revista Jurídica de Castilla y León, n. 33, mayo 2014.

MARTíNEZ-VILLALBA, Juan Carlos Riofrío. El derecho de los secretos. Bogotá: Temis, 2008.

MARTINS, Maria d'Oliveira. Lições de finanças públicas e direito financeiro. Coimbra: Almedina, 2012.

MARTINS, Ives Gandra da Silva e NASCIMENTO, Carlos Valder do (Org.). Comentários à Lei de Responsabilidade Fiscal. São Paulo: Saraiva, 2011.

MARTINS, Ives Gandra da Silva; MENDES, Gilmar Ferreira e NASCIMENTO, Carlos Valder do (Org.). Tratado de direito financeiro. São Paulo: Saraiva, 2013, v. 1.

Tratado de direito financeiro. São Paulo: Saraiva, 2013, v. 2.

MARTINS, Paula (Supervisora). Caminhos da transparência: a Lei de acesso à informação e os tribunais de justiça. São Paulo: Artigo 19 Brasil, 2016.

MARTINS JÚNIOR, Wallace Paiva. Transparência administrativa: publicidade, motivação e participação popular. 2 ed. São Paulo: Saraiva, 2010.

MATOS, Antonio Newton Soares de. Revista do TCU, n. 112, p. 19-30, mai./ago. 2008.

MEDAUAR, Odete. O direito administrativo em evolução. 2.ed. São Paulo: Revista dos Tribunais, 2003.

Tribunais, 2012.

Controle da administração pública. 2. ed. São Paulo: Revista dos

MELLO, Celso Antônio Bandeira. Curso de direito administrativo. 30 ed. São Paulo: Malheiros, 2013. 
MENDEL, Toby. Freedom of information: a comparative legal survey. Paris: UNESCO, 2008.

MENDES, Gilmar Ferreira. Questões fundamentais de técnica legislativa. Revista de Direito Constitucional e Internacional, v. 2, p. 36-52, jan./mar. 1993.

. Lei de Responsabilidade Fiscal, correlação entre metas e riscos fiscais e o impacto dos déficits públicos para as gerações futuras. Fórum de Contratação e Gestão Pública - FCGP, Belo Horizonte, ano 2, n. 14, fev. 2003.

MENDES, Gilmar Ferreira; BRANCO, Paulo Gustavo Gonet. Curso de direito constitucional. 10. ed. São Paulo: Saraiva, 2015.

MENDONÇA, Eduardo Bastos Furtado de. A constitucionalização das finanças públicas no Brasil: devido processo orçamentário e democracia. Rio de Janeiro: Renovar, 2010.

MENDONÇA, Helder Ferreira de. Transparência, condução da política monetária e metas de inflação. Nova Economia, Belo Horizonte, v. 16, n. 1, p. 175-198, jan./abr. 2006.

MENDONÇA, Helder Ferreira de e SIMÃO FILHO, José. Economic transparency and effectiveness of monetary policy. Journal of Economic Studies, v. 34, n. 6, p. 497-514, 2007.

MERLONI, Francesco (Org.). La trasparenza amministrativa. Milano: Giuffrè, 2008.

MIKESELL, John L. Fiscal Administration. 9. ed. Boston: Wadsworth: 2014.

MILESI-FERRETTI, Gian Maria. Good, bad or ugly? On the effects of fiscal rules with creative accounting. Journal of Public Economics, v. 88, n. 1-2, p. 377-394, jan. 2004.

MILESKI, Helio Saul. A transparência da Administração Pública pós-moderna e o novo regime de responsabilidade fiscal. Interesse Público - IP, Belo Horizonte, ano 12, n. 62, jul./ago. 2010.

. O Estado contemporâneo e a corrupção. Belo Horizonte: Fórum, 2015.

MOLINA, José Molina. Por qué la transparencia. Cizur Menor: Aranzadi, 2015.

MORAES, Bernardo Ribeiro. Dívida ativa. São Paulo: Quartier Latin, 2004.

MOREIRA NETO, Diogo de Figueiredo. Curso de direito administrativo. 16. ed. Rio de Janeiro: Forense, 2014.

O direito administrativo do século XXI: um instrumento de realização da democracia substantiva. A\&C - Revista de Direito Administrativo \& Constitucional, Belo Horizonte, ano 11, n. 45, jul./set. 2011. 
MOREIRA NETO, Diogo de Figueiredo; FREITAS, Rafael Véras de. A juridicidade da Lei Anticorrupção: reflexões e interpretações prospectivas. Fórum Administrativo, Belo Horizonte, ano 14, n. 156, fev. 2014.

MORIN, Edgar. O método 1: a natureza da natureza. Trad. Ilana Heineberg. 2. ed. Porto Alegre: Sulina, 2008.

O método 3: conhecimento do conhecimento. Trad. Juremir Machado da Silva. 5. ed. Porto Alegre: Sulina, 2015.

MOURA, Maria Aparecida (Org.). A construção social do acesso público à informação no Brasil: contexto, historicidade e repercussões. Belo Horizonte: UFMG, 2014.

MÜLLER, Friedrich. Quem é o povo? A questão fundamental da democracia. Trad. Peter Naumann. Rev. Paulo Bonavides. 3. ed. São Paulo: Max Limonad, 2003.

O novo paradigma do direito: introdução à teoria e metódica estruturantes. 3. ed. Trad. Ana Paula Barbosa-Fohrmann et. al. São Paulo: Revista dos Tribunais, 2013.

MUSTONEN, Juha (Ed.). The world's first Freedom of Information Act: Anders Chydenius' legacy today. Kokkola: Art-Print, 2006.

NABAIS, José Casalta. Algumas reflexões sobre o actual estado fiscal. Revista Fórum de Direito Tributário - RFDT, Belo Horizonte, ano 1, n. 4, jul./ago. 2003.

O dever fundamental de pagar impostos: contributo para a compreensãoo constitucional do estado fiscal contemporâneo. Coimbra: Almedina, 2009.

NARAYAN, Shilpa. Proper Assertion of the Deliberative Process Privilege: The Agency Head Requirement. Fordham Law Review, v. 77, p. 1183-1220, 2008.

NASCIMENTO, Carlos Valder do. Controle judicial da administração pública a questão da verba indenizatória parlamentar: legitimidade e moralidade. Fórum Administrativo, Belo Horizonte, ano 7, n. 77, jul. 2007.

NECKER, Jacques. Compte rendu au roi. Paris: L'Imprimerie Royale, 1781.

NEVES, Marcelo. Entre Têmis e Leviatã: uma relação difícil. São Paulo: Martins Fontes, 2006.

. Entre Hidra e Hércules: princípios e regras constitucionais. São Paulo: WMF Martins Fontes, 2013.

NICOLÓ, Andreula; CHONG, Alberto. Do good institutions improve fiscal transparency? Economics of Governance, v. 17, n. 3 p. 241-263, aug. 2016. 
NÓBREGA, Maílson. O futuro chegou: instituições e desenvolvimento no Brasil. São Paulo: Globo, 2005.

NOVAIS, Jorge Reis. Os princípios constitucionais estruturantes da República portuguesa. Coimbra: Coimbra, 2004.

NUSSBAUM, Matha C. Creating capabilities: the human development approach. Cambridge: Harvard Univesity Press, 2011.

OFORI, Jerome Jeffison Yaw; LUJALA, Päivi. Illusionary transparency? Oil revenues, information disclosure, and transparency. Society \& Natural Resources: an International Journal, v. 28, n. 11, p. 1187-1202, 2015.

OLIVEIRA, Gustavo Henrique Justino de. As audiências públicas e o processo administrativo brasileiro. Revista de Informação Legislativa, ano 34, n. 135, p. 271-282, jul./set. 1997.

OLIVEIRA, Rafael Carvalho Rezende. O novo marco regulatório das parcerias entre a Administração e as organizações da sociedade civil: aspectos relevantes da Lei $\mathrm{n}^{\circ}$ 13.019/2014. Revista Brasileira de Direito Público - RBDP, Belo Horizonte, ano 12, n. 46, jul./set. 2014.

OLIVEIRA, Regis Fernandes de. Moralidade e impessoalidade administrativa. Revista dos Tribunais, v. 766, p. 107-118, ago. 1999.

. Gastos públicos. São Paulo: Revista dos Tribunais, 2012.

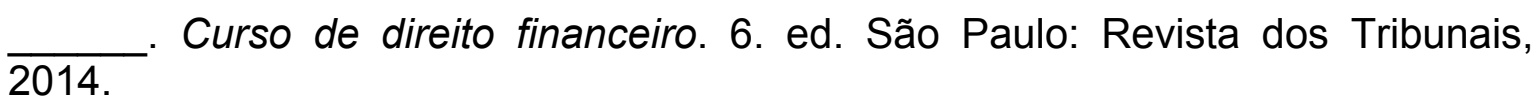
Indagação sobre os limites da ação do Estado. São Paulo: Revista dos Tribunais, 2015.

OLIVEIRA, Regis Fernandes de e ROCHA, Gabriela Marques de Miranda. Liberdade de expressão e internet. Revista de direito das comunicações, v. 4, p. 27-40, jul./dez. 2011.

OLIVEIRA, Weder de. Curso de responsabilidade fiscal: direito, orçamento, finanças públicas. Belo Horizonte: Fórum, 2013, v.1.

OROFINO, Angelo G. Profili giuridici della trasparenza amministrativa. Bari: Caccuci, 2013.

ORWELL, George. 1984. New York: New American Library, 1961.

OST, François. O tempo do direito. Trad. Élcio Fernandes. Bauru: EDUSC, 2005.

PANCRAZI, Laurent. Principe de sincérité budgétaire. Paris: L'Harmattan, 2012.

PARKS, Wallace. Open government principle: applying the right to know under Constitution. The George Washington Law Review, v. 26, n. 1, Oct. 1957. 
PARRY, Taryn. The role of fiscal transparency in sustaining growth and stability in Latin America. Washington: International Monetary Fund, 2007.

PELED, Roy; RABIN, Yoram. The constitutional right to information. Columbia Human Rights Law Review, v. 42, n. 2, p. 357-401, 2011.

PEREZ, Marcos Augusto. A administração pública democrática: institutos de participação popular na administração pública. Belo Horizonte: Fórum, 2009.

PÉREZ LUÑO, Antonio-Enrique. Los derechos fundamentales. 8. ed. Madrid: Tecnos, 2004.

PIERSON, Paul. Increasing returns, path dependence and the study of politics. The American Political Science Review, v. 94, n. 2, p. 251-267, jun. 2000.

PIÑAR MAÑAS, José Luis (Dir.). Transparencia, acceso a la información y protección de datos. Madrid: Reus, 2014.

Transparencia y derecho de acceso a la información pública. Algunas reflexiones en torno al derecho de acceso en la ley 19/2013, de transparencia, acceso a la información y buen gobierno. Revista Catalana de Dret Públic, n. 49, 2014.

PINTO JUNIOR, Mario Engler. A estrutura da administração pública indireta e o relacionamento do Estado com a companhia controlada. Revista de Direito Público da Economia - RDPE, Belo Horizonte, ano 7, n. 28, out./dez. 2009.

PIOTROWSKI, Suzanne J. Governmental transparency in the path of administrative reform. Albany: State University of New York Press, 2007.

PIOVESAN, Flávia; GONZAGA, Victoriana Leonora Corte. Combate à corrupção e ordem constitucional: desafios e perspectivas para o fortalecimento do Estado Democrático de Direito. Revista dos Tribunais, v. 967, p. 21-38, mai. 2016.

PIRES, Valdemir Aparecido. Transparência orçamentária municipal via Internet (TOM Web) no contexto do revigoramento democrático e republicano: uma proposta. III Prêmio SOF de monografias. Disponível a partir de: <http://www.orcamentofederal.gov.br/educacao-orcamentaria>. Acesso em: 19 jul. 2016.

PLATÃO. A República. Trad. Leonel Vallandro. Rio de Janeiro: Nova Fronteira, 2011.

PLATT NETO, Orion Augusto et al. Publicidade e transparência das contas públicas: obrigatoriedade e abrangência desses princípios na administração pública brasileira. Contabilidade Vista \& Revista, Belo Horizonte, v. 18, n. 1, p. 7594, jan./mar. 2007.

PLESKOVIC, Boris; STIGLITZ, Joseph E. (Ed.). Annual World Bank Conference on Development Economics 1999. Washington: World Bank, 2000. 
POLÍBIOS. História. Trad. Mário Gama Kury. Brasília: Universidade de Brasília, 1985.

PUPO, Valentina. Prime note sul segreto di Stato nella dimensione della democrazia rappresentativa. Consulta Online, n.1, abr. 2015.

RANIERI, Nina. Teoria do Estado: do Estado de Direito ao Estado Democrático de Direito. Barueri: Manole, 2013.

RAZ, Joseph. The authority of law: essays on law and morality. Second Edition. New York: Oxford University Press, 2009.

REALE, Miguel. O direito como experiência: introdução à epistemologia jurídica. 2. ed. São Paulo: Saraiva, 1992.

. Filosofia do direito.19 ed. São Paulo: Saraiva, 1999.

. Lições preliminares de direito. 27. ed. São Paulo: Saraiva, 2004.

RICCIO, Edson Luiz; TEIXEIRA, Marco Antonio Carvalho; ZUCCOLOTTO, Robson. Transparência: reposicionando o debate. Revista Contemporânea de Contabilidade, Florianópolis, v. 12, n. 25, p. 137-158, jan./abr. 2015.

ROCHA, Cármen Lúcia Antunes. Princípios constitucionais da administração pública. Belo Horizonte: Del Rey, 1993.

ROMÃO, Miguel Lopes. A bem do Estado: publicidade e segredo na formação e na divulgação das leis (1820-1910). Coimbra: Almedina, 2005.

ROSE-ACKERMAN, Susan. Corruption and government: causes, consequences and reform. New York: Cambridge University Press, 1999.

ROSS, Alf. Tû-Tû. Trad. Edson L.M. Bini. São Paulo: Quartier Latin, 2004.

ROSS, Michael L. The oil curse: how petroleum wealth shapes the development of nations. Princenton: Princenton University Press, 2012.

ROUSSEAU, Jean-Jacques. Rousseau e as relações internacionais. Trad. Sérgio Bath. São Paulo: Imprensa Oficial, 2003.

RUBINSTEIN, Flávio. Boa-fé objetiva no direito financeiro e tributário. São Paulo: Quartier Latin, 2010.

SÁEZ, Manuel Arenilla (Dir.). Crisis y reforma de la Administración Pública. Oleiros: Netbiblo, 2011.

SAINZ DE BUJANDA, Fernando. Estado de Derecho y hacienda publica. Revista de Administración Pública, n. 6, p. 193-212, 1951.

$\overline{\text { Madrid, }} 1967$.

Teoria de la educacion tributaria. Madrid: Universidad Complutense de 
SALDANHA, Nelson. O jardim e a praça: o privado e o público na vida social e histórica. São Paulo: EDUSP, 1993.

. Estado, jurisdição e garantias: um capítulo de história constitucional. Revista da Faculdade de Direito da Universidade de São Paulo, v. 74, p. 139-152, jan. 1979.

SALTO, Felipe e ALMEIDA, Mansueto (Org.). Finanças públicas. Rio de Janeiro: Record, 2016.

SÁNCHEZ SERRANO, Luis. Tratado de derecho financiero y tributario constitucional. Madrid: Marcial Pons, 1997, v.1.

SANTI, Eurico Marcos Diniz de. et. al. Transparência fiscal e desenvolvimento: homenagem ao Professor Isaias Coelho. São Paulo: Fiscosoft, 2013.

SARLET, Ingo Wolfgang; MARTOS, José Antonio Montilla; RUARO, Regina Linden (Coord.). Acesso à informação como direito fundamental e dever estatal. Porto Alegre: Livraria do Advogado, 2016.

SCHAUER, Frederick. Transparency in three dimensions. University of Illinois Law Review, n. 4, p. 1339-1358, 2011.

SCAFF, Fernando Facury. Tributação e políticas públicas: o ICMS ecológico. Revista de Direito Ambiental, v. 38, p. 99-120, abr./jun. 2005.

Royalties do petróleo, minério e energia: aspectos constitucionais, financeiros e tributários. São Paulo: Revista dos Tribunais, 2014.

Crédito público e sustentabilidade financeira. Revista Fórum de Direito Financeiro e Econômico - RFDFE, Belo Horizonte, ano 3, n. 5, p. 55-68, mar.lago. 2014.

Crônicas de direito financeiro: tributação, guerra fiscal e políticas públicas. São Paulo: Conjur, 2016.

SCAFF, Fernando Facury (Org.). Constitucionalismo, tributação e direitos humanos. Rio de Janeiro: Renovar, 2007.

SCAFF, Fernando Facury e CONTI, José Maurício. Lei de Responsabilidade Fiscal: 10 anos de vigência - questões atuais. Florianópolis: Conceito Editorial, 2010.

SCAFF, Fernando Facury; ROMBOLI, Roberto e REVENGA, Miguel (Coord.). A eficácia dos direitos sociais. São Paulo: Quartier Latin, 2010.

SCHMITT, Carl. La dictadura. Desde los comienzos del pensamiento moderno de la soberanía hasta la lucha de clases proletaria. Trad. José Díaz García. Madrid: Revista de occidente, 1968. 
.Teoría de la Constitución. Versión española de Francisco Ayala. Madrid: Alianza, 1996.

SCHOUERI, Luís Eduardo. Direito tributário. São Paulo: Saraiva, 2011.

SEN, Amartya. Development as freedom. New York: Alfred A. Knopf, 2000.

SENELLART, Michel. As artes de governar: do regimen medieval ao conceito de governo. Trad. Paulo Neves. São Paulo: 34, 2006.

SHAH, Anwar (Ed.). Budgeting and budgetary institutions. Washington: The World Bank, 2007.

SHAH, Anwar; SCHACTER, Mark. Combating corruption: look before yout leap. Finance \& Development, p. 41-43, December 2004.

SHANNON, Claude E. A mathematical theory of communication. The Bell System Technical Journal, v. 27, p. 379-423, 1948.

SHAPIRO, lan. The state of democratic theory. New Jersey: Princeton University Press, 2003.

2003.

. The moral foundations of politics. New Heaven: Yale University Press,

SILVA, Anderson Caputo; CARVALHO, Lena Oliveira de. e MEDEIROS, Otavio Ladeira de (Org.). Dívida Pública: a experiência brasileira. Brasília: Secretaria do Tesouro Nacional, 2009.

SILVA, José Afonso da. Orçamento-programa no Brasil. São Paulo: Revista dos Tribunais, 1973.

2011.

. Curso de direito constitucional positivo. 34. ed. São Paulo: Malheiros,

SILVA, Virgílio Afonso. O proporcional e o razoável. Revista dos Tribunais, v. 798, abr. 2002.

. Princípios e regras: mitos e equívocos acerca de uma distinção. Revista Latino-Americana de Estudos Constitucionais, v. 1, p. 607-630, 2003.

. O Supremo Tribunal precisa de lolau: resposta às objeções de Marcelo Neves ao sopesamento e à otimização. Revista de Direito da Universidade de Brasília, v. 2, n. 1, jan./abr. 2016.

SILVEIRA, Alexandre Coutinho da. Governança pública de royalties: federalismo fiscal e futuras gerações. Dissertação de Mestrado. Faculdade de Direito da Universidade de São Paulo, São Paulo, 2016.

SIMMEL, Georg. The sociology of secrecy and of secret societies. American Journal of Sociology, v. 11, n. 4, jan. 1906. 
SNYDER, Jon R. Dissimulation and the culture of secrecy in early modern Europe. Berkeley: University of California Press, 2009.

SOLL, Jacob. The information master: Jean-Baptiste Colbert's secret state intelligence system. Ann Arbor: The University of Michigan Press, 2009.

SOUTO, Marcos Juruena Villela. O papel da Advocacia Pública no controle da legalidade da Administração. Interesse Público - IP, Belo Horizonte, n. 28, ano 6, nov./dez. 2004.

SPINOZA, Benedictus de. Tratado político. Trad. Diogo Pires Aurélio. São Paulo: WMF Martins Fontes, 2009.

STAROBINSKI, Jean. Jean-Jacques Rousseau: a transparência e o obstáculo. Trad. Maria Lúcia Machado. São Paulo: Companhia das Letras, 2011.

SUETONIUS. The lives of the twelve ceasars. Edited with notes and an introduction by Joseph Gavorse. New York: Modern Library, 1931.

SUNDFELD, Carlos Ari. Princípio da publicidade administrativa (direito de certidão, vista e intimação). Revista de Direito Administrativo, n. 199, Rio de Janeiro, jan./mar. 1995.

SUNDFELD, Carlos Ari; SOUZA, Rodrigo Pagani de; PINTO, Henrique Motta. Empresas semiestatais. Revista de Direito Público da Economia - RDPE, Belo Horizonte, ano 9, n. 36, out./dez. 2011.

SURREY, Stanley S. Pathways to tax reform: the concept of tax expenditure. Cambridge: Harvard University Press, 1973.

TANZI, Vito. Corruption around the world: causes, consequences, scope and cures. IMF Working Paper 98/63. Washington: International Monetary Fund, 1998.

TAVARES, André Ramos. A categoria dos preceitos fundamentais na Constituição brasileira. Revista de Direito Constitucional e Internacional, v. 34, p. 105-133, jan./mar. 2001.

Responsabilidade fiscal: novos parâmetros para o poder público. Revista Brasileira de Ciências Criminais, v. 36, out. 2001.

TAYLOR, Roger; KELSEY, Tim. Transparency and the open society: practical lessons for effective policy. Bristol: Policy Press, 2016.

TESTA JÚNIOR, Washington Luiz. Informação, direito e verdade: regulação constitucional da imprensa. Curitiba: Juruá, 2011.

THOMPSON, Dennis F. Democratic secrecy. Political Science Quarterly, v. 114, n. 2, 1999. 
TORRE, Alessandro (Dir.). Costituzioni e sicurezza dello Stato. Dogana: Maggioli, 2013.

TORRES, Ricardo Lobo. A legitimidade democrática e o Tribunal de Contas. Revista de Direito Constitucional e Internacional, v. 4, p. 185-198, jul./set. 1993.

. Tratado de direito constitucional financeiro e tributário, volume II: valores e princípios constitucionais tributários. Rio de Janeiro: Renovar, 2005.

- Tratado de direito constitucional financeiro e tributário, volume III: os direitos humanos e a tributação: imunidades e isonomia. Rio de Janeiro: Renovar, 2005.

2008.

. Curso de direito financeiro e tributário. 15. ed. Rio de Janeiro: Renovar,

- Tratado de direito constitucional financeiro e tributário, volume V: o orçamento na Constituição. 3. ed. Rio de Janeiro: Renovar, 2008.

- Tratado de direito constitucional financeiro e tributário, volume l: Constituição financeira, sistema tributário e Estado fiscal. Rio de Janeiro: Renovar, 2009.

TORRES, Heleno Taveira. Direito constitucional tributário e segurança juridica: metódica da segurança juridical do sistema constitucional tributário. São Paulo: Revista dos Tribunais, 2011.

. Direito constitucional financeiro: teoria da Constituição financeira. São Paulo: Revista dos Tribunais, 2014.

TORRES, Heleno Taveira (coord.). Direito e poder nas instituições e nos valores do público e do privado contemporâneos: estudos em homenagem a Nelson Saldanha. Barueri: Manole, 2005.

TRUELOVE, Andreanna M. Oil, diamonds, and sunlight: fostering human rights through transparency in revenues from natural resources. Georgetown Journal of International Law, v. 35, p. 207-237, 2003.

TUCÍDIDES. História da Guerra do Peloponeso. Trad. do grego de Mário da Gama Kury. 4. ed. Brasília: Universidade de Brasília, Instituto de Pesquisa de Relações Internacionais, 2001.

UNESCO. Towards knowledge societies. Paris: United Nations Educational, 2005.

UNITED NATIONS. Auditing for social change: A strategy for citizen engagement in public sector accountability. New York: United Nations, 2007.

VALENTE, Ana Paola de Morais Amorim. Transparência e opacidade: o siafi no acesso à informação orçamentária. Belo Horizonte: FUMEC, 2004. 
VALIM, Rafael; MALHEIROS, Antonio Carlos; BACARIÇA, Josephina (Coord.). Acesso à informação pública. Belo Horizonte: Fórum, 2015.

VEIGA, Clóvis de Andrade. Direito financeiro aplicado: planejamento, elaboração, execução e controle orçamentário. São Paulo: Revista dos Tribunais, 1975.

VEIGA FILHO, João Pedro da. Manual da sciencia das finanças. 4. ed. São Paulo: Monteiro Lobato, 1923.

VERDÚ, Pablo Lucas. La Constitución en la encrucijada (palingenesia iuris politici). Pensamiento Constitucional, año IV, n. 4.

VIANA, Arizio de. Orçamento brasileiro. 2. ed. Rio de Janeiro: Edições Financeiras, 1950.

VIDIGAL, Geraldo. Elementos do direito financeiro. São Paulo: Revista dos Tribunais, 1973.

VIEIRA, Luís Eduardo P. de O. Transparência e controle da gestão fiscal: a Lei Complementar $n^{\circ} 131 / 09$ e sua regulamentação. Revista Técnica dos Tribunais de Contas - RTTC, Belo Horizonte, ano 2, n. 1, set. 2011.

VILANOVA, Lourival. As estruturas lógicas e o sistema de direito positivo. São Paulo: Noeses, 2005. . Escritos jurídicos e filosóficos. São Paulo: Axis Mundi IBET, 2003, v. 1.

Tribunais, 2000 . - Causalidade e relação no direito. 4. ed. São Paulo: Revista dos

VILLAVERDE MENÉNDEZ, Ignacio. Los derechos del público. Madrid: Tecnos, 1995.

VILLEGAS, Héctor B. Curso de finanzas, derecho financiero e tributario. 7 ed. Buenos Aires: Depalma, 2001.

WALLIS, John Joseph. The concept of systematic corruption in American political and economic history. Working Paper n. 10952. Disponível em: <http://www.nber.org/papers/w10952>. Acesso em: 14 fev. 2016.

WARREN, Samuel D.; BRANDEIS, Louis D. The right to privacy. Harvard Law Review, v. 4, n. 5, dec. 1890.

WENCES, Isabel; KÖLLING, Mario; RAGONE, Sabrina (Coord.). La ley de transparencia, acceso a la información pública y buen gobierno: una perspectiva académica. Madrid: CEPC, 2014.

WILLIAMS, Bernard. Truth and truthfulness: an essay in genealogy. Princeton: Princeton University Press, 2002. 
WINKLER, Bernhard. Which kind of transparency? On the need for clarity in monetary policy-making. Working Paper n. 26, European Central Bank, 2000.

ZEPEDA, Jesús Rodríguez. Estado y transparencia: un paseo por la filosofía política. México: Instituto Federal de Acceso a la Información Pública - IFAI, 2004.

ZOLLER, Elisabeth; GUGLIELMI, Gilles-J. (Dir.). Transparence, démocratie et gouvernance citoyenne. Paris: Editions Panthéon-Assas, 2014. 